\title{
Article \\ The COVID-19 Pandemic and Commercial Property Rent Dynamics
}

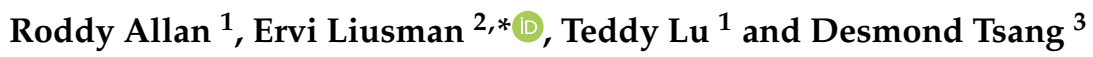 \\ 1 Jones Lang LaSalle (JLL), 7/F One Taikoo Place, Hong Kong, China; roddy.allan@ap.jll.com (R.A.); \\ teddysg.lu@ap.jll.com (T.L.) \\ 2 School of Hotel and Tourism Management, The Chinese University of Hong Kong, 7/F Cheng Yu Tung \\ Building, 12 Chak Cheung Street, Shatin, N.T., Hong Kong, China \\ 3 Desautels Faculty of Management, McGill University, 1001 Sherbrook Street West, Montreal, QC H3A 1G5, \\ Canada; desmond.tsang@mcgill.ca \\ * Correspondence: ervi@baf.cuhk.edu.hk
}

Citation: Allan, Roddy, Ervi Liusman, Teddy Lu, and Desmond Tsang. 2021. The COVID-19 Pandemic and Commercial Property Rent Dynamics. Journal of Risk and Financial Management 14: 360. https://doi.org/10.3390/jrfm14080360

Academic Editor: Kim Hiang Liow

Received: 16 June 2021

Accepted: 1 August 2021

Published: 6 August 2021

Publisher's Note: MDPI stays neutral with regard to jurisdictional claims in published maps and institutional affiliations.

Copyright: (c) 2021 by the authors. Licensee MDPI, Basel, Switzerland. This article is an open access article distributed under the terms and conditions of the Creative Commons Attribution (CC BY) license (https:/ / creativecommons.org/licenses/by/ $4.0 /)$.
Abstract: This paper utilizes timely proprietary data to examine the contemporary impact of the COVID-19 pandemic on commercial property rent dynamics in the Asia-Pacific region. Given that the Asia-Pacific region was the first to be impacted by the public health crisis, it is important to examine how the COVID-19 pandemic has affected the real estate markets in this region and to assess how the region has been recovering since then. Our regression analysis, controlling for different macroeconomic fundamentals and city and property type fixed effects, documents substantial declines in rents of approximately 15\% during the first six months of 2020 across the Asia-Pacific commercial property market. We further observe that the most significant declines in rent occur in regions where exposure to the COVID-19 pandemic is the more severe, and in the retail property sector, where we have been observing continued declines of over $30 \%$, with little recovery as of the second quarter of 2020. In additional analysis, we examine capital values and show that while capital targeting the retail property sector has been muted, there is some evidence showing capital flows into the residential and industrial sectors. We also show that fiscal stimuli imposed by governments have moderated the adverse impact of the pandemic. Overall, our study shows that while the effect of the COVID-19 public health crisis is detrimental to commercial real estate, its impact varies significantly across different regions and property sectors.

Keywords: COVID-19; rent dynamics; commercial property; Asia-Pacific market; capital values; fiscal policy

\section{Introduction}

The COVID-19 pandemic has had a profound impact on the lives and livelihoods of people all over the world, with important short-term and potential long-lasting effects on how people live, work and play. In our highly globalized economy of the 21st century, where international travel and logistics have been made easier than ever before, there have been demonstrated benefits in cross-border exchanges of goods, services, information, people, talent and capital, thereby promoting economic growth and development on a global scale. Unfortunately, this also facilitated the swift spread of the COVID-19 virus, upending global societies and economies.

Since the first cases of the COVID-19 virus were discovered in December 2019, the virus was spreading rapidly, with cases reported and rapidly rising in China, South Korea, Japan, Singapore, and beyond (e.g., Griffiths 2020; Pettersson et al. 2020; Zhang et al. 2020). The efficient nature in which the virus was able to spread from person to person, that people infected with the virus who showed no symptoms were able to spread the virus to others, and the ease and prevalence of international travel have all contributed to the contagion of COVID-19 across the Asia-Pacific region and all over the world. By the 
end of August 2020, confirmed cases in the Asia-Pacific region totaled 3.5 million, with 142,000 deaths. Figure 1 displays the distribution of COVID-19 cases and deaths across the Asia-Pacific region. Globally, there were 25 million confirmed cases, and a total of 847,000 deaths. With so many people suffering symptoms, so many lives lost and so many countries affected, the human cost of this pandemic has been epic and the damage tragic.

\section{Confirmed Cases and Deaths}

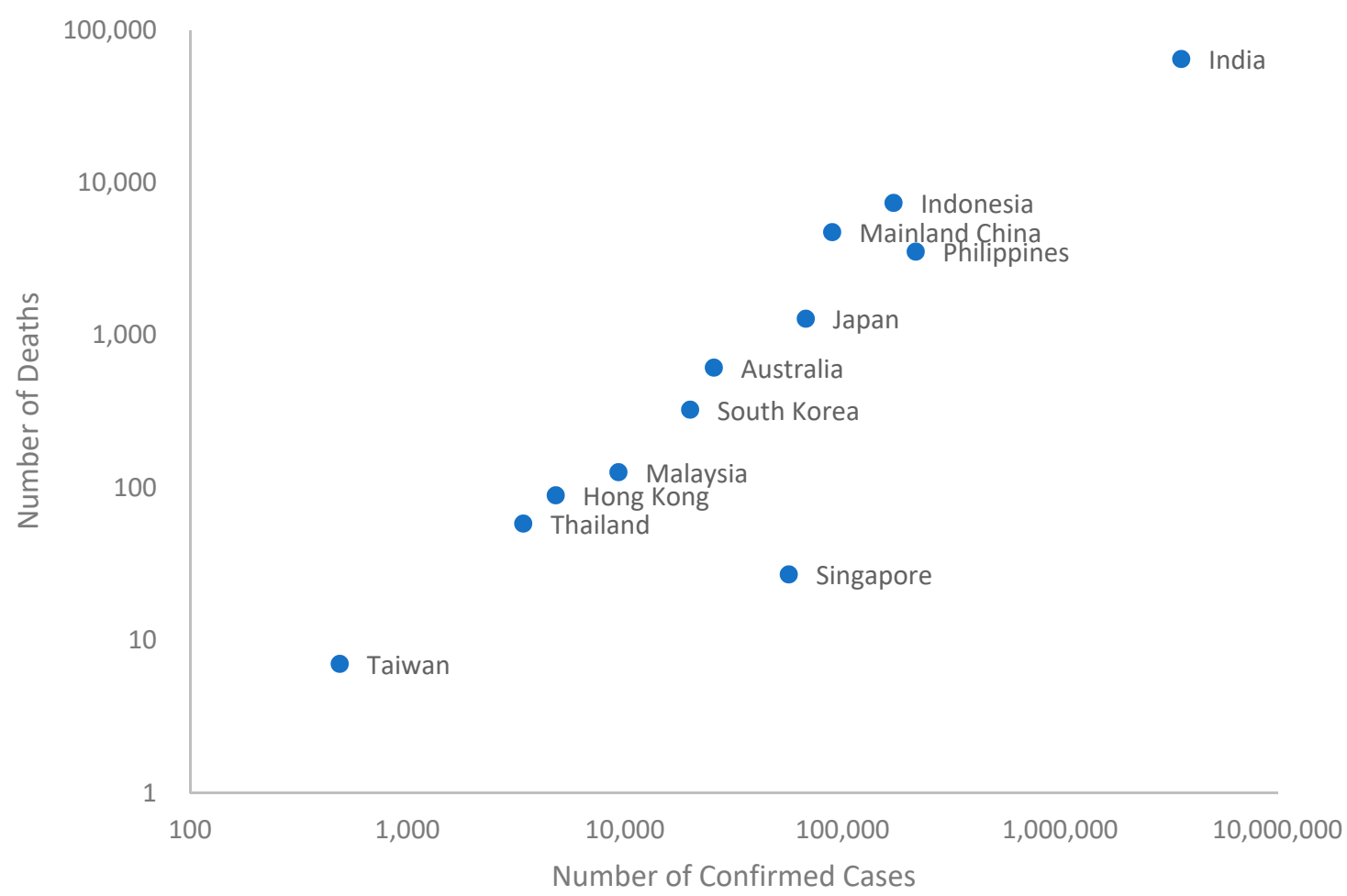

Figure 1. Total Confirmed Cases and Deaths due to COVID-19 as of the End of August 2020 in the Asia-Pacific region. Source: Our World in Data.

In addition to the damage in terms of public health and human lives that this pandemic has caused, the vast economic damage manifested in the forms of lost economic output, job losses, disrupted supply chains and upended livelihoods has also been undeniable. The first few months of the pandemic brought an economic impact on a scale and speed not seen before, with China's economy contracting by $8.5 \%$ and followed by the rest of the Asia-Pacific region in a similar fashion (Rogers 2020). The pandemic subsequently brought an unprecedented crisis to the global economy, with the OECD predicting world GDP to decline by up to $7.6 \%$ for 2020 (OECD 2020b). A variety of factors, ranging from general public caution and social distancing measures to government-imposed lockdowns and travel restrictions, have resulted in a massive slowdown in economic activities. Temporary closures of shopping malls, cinemas, retail stores and restaurants have inevitably led to the furloughs of the retail and food and beverage (F\&B) industries, leaving workers without a source of income. ${ }^{1} \mathrm{~A}$ halt to international travel has inexorably crippled the hospitality and tourism industries, with international tourism falling by 72\% in 2020 (UNWTO 2020). The closure of factories and food-processing plants to mitigate the spread of the COVID-19 virus has led to disruptions in supply chains, which caused fear of supply shortages of everyday items and drove people to panic buy and hoard goods such as groceries and toilet paper. In some even more unfortunate scenarios, many businesses were forced to close and to file for bankruptcy, leading to permanent job losses and loss of income sources for families. 
Prior to the outbreak of the virus, commercial real estate spaces played an integral part of people's lives: white-collar workers typically spend a huge chunk of their time in an office setting, consumers normally visit shopping malls and retail stores to do their essential or discretionary shopping, and people from all walks of life patronize bars and restaurants to enjoy food and drinks, and to socialize. When the pandemic first impacted the Asia-Pacific region and then continued to spread across the world, the real estate sector felt the first impact (JLL 2020b). Suddenly, workers turned to work-from-home arrangements, shoppers began utilizing e-commerce platforms to fulfill their retail needs and desires, and diners were forced to resort to food delivery or takeout orders. Naturally, the impact of these phenomena has significant immediate consequences on the commercial property market. Commercial real estate investment transaction volume has fallen by $29 \%$ globally within the first six months of 2020, and inter-regional investment has declined by $61 \%$ during the second quarter (JLL 2020a). As the Asia-Pacific region was the first to be majorly impacted by the outbreak, the region took a huge hit, with transaction volumes down by $32 \%$ in the first half of 2020 (JLL 2020a). Moreover, a report by Invesco (2020) opines that the COVID-19 pandemic could have a prolonged and far-reaching impact on the commercial real estate market due to weakened occupier demand for office space, falls in foot traffic and spending in prime retail districts, and wider adoption of technology such as automation in logistics spaces.

This study utilizes timely proprietary data from JLL to examine the contemporary impact of the COVID-19 pandemic on commercial property rent dynamics in the AsiaPacific region. Importantly, the Asia-Pacific commercial property market has been one of the strongest economic drivers of the region and of the world, recording a transaction volume of $\$ 45$ billion as of 2019 and outperforming the Americas, Europe, the Middle East and Africa (Tay 2019). Hence, it is important to examine how the COVID-19 pandemic has affected the real estate markets in the region. Given that the region was the first to be impacted by the public health crisis, it is also vital to assess how recoveries, if any, have been underway. Moreover, the localized nature of the pandemic, where regions are vastly different in terms of their exposure to the pandemic, has created a distinct divergence among markets (JLL 2020a). The COVID-19 pandemic also affects different property sectors in different ways. For instance, the retail property sector has suffered in many regions due to the imposition of social distancing and forced lockdowns. The office property sector may also be severely affected by the ongoing work-from-home arrangements for firms in many regions. Therefore, it is essential to further examine the differential impact of the COVID-19 pandemic on different property sectors across the Asia-Pacific region.

Our data cover the sample period from the first quarter of 2010 to the second quarter of 2020, which is in the midst of the COVID-19 pandemic. We obtain JLL data for market rents and capital values on 38 cities in 12 countries and jurisdictions across the Asia-Pacific region. Our regression analysis, controlling for different macroeconomic fundamentals and city and property type fixed effects, documents and quantifies substantial declines in market rents of an average of approximately 15\% during the first six months of 2020 across the Asia-Pacific commercial property market. Moreover, we observe that higher declines in rent occur in regions where exposure to the COVID-19 pandemic is more severe, as we show a negative relationship between market rent and the number of COVID-19 confirmed cases and deaths by region. Across the property sector, we observe moderate declines of approximately $14 \%$ in market rent for office properties. However, in the retail property sector, we have been observing the most significant and continued declines in market rent, as our empirical findings indicate a decline of over $30 \%$ during the first six months with little recovery in sight as of the second quarter of 2020.

In additional analysis, we examine capital values and show that, surprisingly, capital values for the commercial property market, as a whole, have not fallen considering the pandemic. However, further analysis shows that capital values drop significantly for the retail property sector. There also exists some evidence that capital flows into the residential and industrial sectors. The findings demonstrate that there might be some reshuffling 
of capital within the commercial property market. The results confirm, with anecdotal evidence, that investors may be pursuing more defensive strategies in the midst of the pandemic, reallocating funds to sectors that have proved operationally critical throughout the pandemic, such as the industrial and residential sectors, and investors might select alternative commercial real estate investments such as data centers (Gilchrist 2020). Given that most countries and jurisdictions have provided various fiscal stimuli to mitigate the impact of the pandemic, we next examine the moderating effect of these stimuli on the impact of the COVID-19 pandemic on commercial property rent. We find that fiscal stimuli exert a generally significantly positive effect in curbing the decline in commercial rent during the pandemic. In robustness analysis, we have replicated our analysis with different sample subperiods, with a different subsample excluding mainland China, which constitutes a substantial proportion of our sample cities, and with alternative measures of the severity of the COVID-19 pandemic. Our results remain robust with these alternative specifications.

Our study makes the following contributions. First, we provide novel evidence of the impact of the COVID-19 pandemic on the commercial property market. Our study relates to the fast-growing literature examining the COVID-19 pandemic on firms and the economy (e.g., Alfaro et al. 2020; Baker et al. 2020; Chen et al. 2020; De Vito and Gomez 2020; Gerding et al. 2020; Ozili and Arun 2020; Schoenfeld 2020). In particular, we are among the first several studies on the real estate market (Akinsomi 2020; D'Lima et al. 2020; Ling et al. 2020; Milcheva 2020; Xie and Milcheva 2020; Van Dijk et al. 2020; Zhao 2020). Since the illiquidity and opaqueness of private commercial real estate markets limit the ability to detect rent and price movement in real time (Ling et al. 2020), most of these concurrent studies look at stock market responses of REITs and real estate equities in forming expectations of the pandemic for the real estate market (Akinsomi 2020; Ling et al. 2020; Milcheva 2020; Xie and Milcheva 2020). On the other hand, D'Lima et al. (2020) and Zhao (2020) utilize residential transaction data in the U.S., but both studies find little negative effect of the COVID-19 pandemic on residential housing prices. Van Dijk et al. (2020) examine transaction data in the U.S. to quantify the effect of the pandemic on the commercial real estate market. However, their study could only document a drop in market liquidity, but not for price, and the authors claim that it is because of the stickiness in price that results in market liquidity leading price movement. While our study also utilizes real transaction data from the commercial property market to provide insight on how the market is being affected by the pandemic, our research design and setting provide us with some distinct advantages. First, market rent has long been considered an important determinant of housing price (e.g., Gallin 2008; Campbell et al. 2009), and is by itself one important metric of the demand and supply of commercial real estate. However, despite its importance, there is limited availability of commercial rental data (An et al. 2016; Wheaton et al. 1997b). By utilizing proprietary market rent data from JLL, we provide some time-relevant quantifiable evidence on to what extent the commercial property market has been adversely impacted by the pandemic. Second, by focusing on the Asia-Pacific market, where the COVID-19 pandemic initially had the greatest impact, we should be able to better capture the longer-run impact of the pandemic and its recovery, if any, on this region.

Our study also contributes to the broader literature examining the impact of a public health crisis on the economy (e.g., Barro et al. 2020; Bleakley 2007; Chou et al. 2004; Correia et al. 2020; Keogh-Brown et al. 2010; Lilley et al. 2020) and the relatively scarce literature on the residential real estate market (Ambrus et al. 2020; Francke and Korevaar 2021; Wong 2008). Specifically, we show how an unprecedented public health crisis such as the COVID-19 pandemic can wreak havoc on rent dynamics in the commercial property market. In so doing, we also add to the literature examining macroeconomic fundamentals on rent dynamics (e.g., Brounen and Jennen 2009; D'Arcy et al. 1999; De Francesco 2008; Hendershott et al. 2002a, 2002b, 2010; Ibanez and Pennington-Cross 2013; Slade 2000). Yet, we offer a new perspective to the literature by focusing on how an external shock can 
influence the functioning of the commercial property market (e.g., Goodhart and Hofmann 2008; Chau and Wong 2016).

The rest of this paper is organized as follows. The next section reviews related literature. Section 3 presents sample data and descriptive statistics. Section 4 outlines our research design and reports the main empirical findings. We discuss additional and robustness analysis in Section 5 and offer our concluding remarks in Section 6.

\section{Literature Review}

\subsection{Recent Literature on the Economic Impact of the COVID-19}

Our paper is related to recent studies that examine various impacts of the COVID-19 pandemic on firms and the economy. There is a wealth of literature on the impact of COVID-19 on the economy as a whole. For instance, Baker et al. (2020) document that the adverse impact of the COVID-19 pandemic on the stock market and the economy is more intense than previous pandemics. Ozili and Arun (2020) reveal that the increasing number of lockdowns as well as travel restrictions have both contributed to lower levels of economic activities. Gerding et al. (2020) show that stock returns react more negatively in countries with higher debt-to-GDP ratios during the COVID-19 pandemic, suggesting a country's fiscal capacity is a key determinant of mitigating the pandemic effect. De Vito and Gomez (2020) show that the COVID-19 pandemic has seriously affected the liquidity of firms across the world, in which they predict in their model 10\% of firms would become illiquid within six months from the onset of the pandemic.

At the firm level, Alfaro et al. (2020) show unanticipated changes in predicted infections forecast aggregate as well as firm-level stock returns. Schoenfeld (2020) find that while firm managers systematically underestimate their firms' exposure to the pandemic, the vast majority of firms decreased in value at the onset of the pandemic. Chen et al. (2020) show that returns are lower for firms headquartered in U.S. states following lockdown announcements, but different when the county has a high number of infections. They interpret these results as indication that government policy intervention could have mixed effects on the economy. Many recent studies have also focused on the impact of different firm fundamentals on company performance during the COVID-19 pandemic (e.g., Acharya and Steffen 2020; Albuquerque et al. 2020; Ding et al. 2020a, 2020b; Fahlenbrach et al. 2020; Hassan et al. 2020; Li et al. 2021; Pagano et al. 2020; Papanikolaou and Schmidt 2020; Ramelli and Wagner 2020; Shan and Tang 2020).

Given the immense impact of the COVID-19 pandemic on the stock market and the economy, it comes as no surprise that the global real estate market is also strongly affected by the pandemic. In a special report by the MIT Center for Real Estate, Van Dijk et al. (2020) quantify the impact of the pandemic on the private commercial property market by analyzing market liquidity in eight major U.S. markets. They demonstrate a substantial decline in liquidity in all markets since the beginning of the pandemic. They also show that the recent drop in market liquidity represents the most serious drop since the Global Financial Crisis (GFC), and in magnitude, the drop in the first four months of 2020 alone is already a substantial fraction of the total liquidity drop of the entire GFC. Both D'Lima et al. (2020) and Zhao (2020) provide the first evidence of housing price changes in the midst of the COVID-19 for the U.S. residential real estate market. Zhao (2020) shows that the growth rates of median residential house price slowed in March and April but quickly bounced back after April, and the author claims that the impact of the COVID19 is minimal in the U.S. residential market. D'Lima et al. (2020) present a first view on the effect of shutdown responses to the COVID-19 pandemic but find no aggregate pricing effect of the shutdown orders. Ling et al. (2020) construct a novel measure of listed commercial real estate (CRE) portfolios' exposure to the growth in COVID-19 cases using a granular sample of firms' individual commercial property holdings in the U.S., and they document a negative relationship between COVID-19 case growth and real estate firms' risk-adjusted returns. They also show that the impact of the COVID-19 pandemic on real estate firms differs across property types, with the retail and hospitality sectors 
reacting the most negatively while the technology sector reacts positively to the COVID-19 pandemic. Similarly, Akinsomi (2020) also show that most REITs have decreased in value during the pandemic, but some REITs, such as data REITs, grocery-anchored REITs and storage REITs, are less adversely affected by the COVID-19 pandemic. Milcheva (2020) tests the co-movement of real estate equities and the general stock market. The study shows that such correlation increases dramatically during the pandemic, and there exists large differences across real estate sectors, with the retail sector exhibiting the highest sensitivity. Xie and Milcheva (2020) examine the effect of proximity to COVID-19 cases on real estate firm returns, and they find a significantly negative effect of the COVID-19 pandemic.

\subsection{Literature on the Economic Impact of Other Pandemics}

Extant literature has also examined the impact of other historical health pandemics on the economy. Few recent papers have re-examined historical pandemics for insights on the long-term consequences of the COVID-19 pandemic. For instance, Barro et al. (2020); Correia et al. (2020); and Lilley et al. (2020) all examine flu deaths during the "Spanish Flu" pandemic, and the general consensus is that the pandemic generated significant economic decline for GDP, and that high flu death rates decreased realized real returns on stocks and short-term government bills. However, in the long run, the economy was able to bounce back and recover. Keogh-Brown et al. (2010) show that the 1957 and the 1968 pandemics in the United Kingdom constituted a loss of $3.35 \%$ and $0.58 \%$ of GDP, respectively. In the Asian context, Chou et al. (2004) shows that for the Severe Acute Respiratory Syndrome (SARS) outbreak, losses to GDP of the service and manufacturing sectors amounted to $0.67 \%$ in Taiwan, $0.20 \%$ in mainland China, and $1.56 \%$ in Hong Kong. For the financial market, Lagoarde-Segot and Leoni (2013) show that the likelihood of a collapse of the banking industry of a developing country increases as the joint prevalence of large pandemics such as AIDS and malaria increases. Wachter (2013) shows that the possibility of a rare disaster such as a pandemic substantially increases stock market equity premium, while time variation in the probability of this outcome drives high stock market volatility and excess return predictability. On the other hand, Bleakley (2007) shows that the successful eradication of a pandemic, on the hookworm disease from the American South which started circa 1910, helped lead to greater economic and demographic development.

The real estate literature on the impact of other health pandemics is scarce. Ambrus et al. (2020) study the impact of the 19th-century Cholera epidemic on the housing market in London. They find that housing prices are significantly lower in the neighborhood that transmitted the disease even 10 years after the epidemic. They attribute the findings to a locally concentrated income shock that persistently changed the tenant composition of a neighborhood. Francke and Korevaar (2021) study the historical outbreaks of the plague in 17th-century Amsterdam and cholera in 19th-century Paris and their impact on urban housing markets, and they show that outbreaks result in large declines in housing prices, and smaller declines in rent prices. The study also shows particularly large reductions in house prices during the first six months of an epidemic, and in heavily affected areas. However, these price shocks were only transitory, and both cities quickly reverted to their initial price paths. Wong (2008) used the 2003 Hong Kong SARS pandemic as a natural experiment to investigate how housing markets react to extreme events. The study shows an average price decline of 1-3\% if a housing estate is directly affected by SARS, and an average of $1.6 \%$ for all estates as a result of the outbreak of the disease.

\subsection{Literature on Real Estate Cycle and Rent Dynamics}

There exists vast literature showing that real estate cycles are affected by macroeconomic fundamentals. For example, Adams and Füss (2010) show that long-term housing prices can be explained by economic activity, construction cost and long-term interest rate. Baffoe-Bonnie (1998) shows that macroeconomic variables such as employment growth and mortgage rate have significant impacts on the dynamic behavior of housing prices and the number of houses sold, but the impact varies in different regions and at different time 
periods. Focusing on the California housing markets, Edelstein and Tsang (2007) further show that local macroeconomic fundamentals are more important determinants of real estate cycles than national and regional fundamentals. Goodhart and Hofmann (2008) also show significant multidirectional links between house prices, monetary variables, and the economy, and these relationships are stronger when house prices are booming. However, there is also evidence showing that real estate prices can deviate from their fundamentals and this can take a long time to reverse (e.g., Mikhed and Zemčík 2009).

Our study is particularly related to the literature examining rent dynamics. Earlier studies predominantly focus on the interrelationships of rent and vacancy (e.g., Blank and Winnick 1953; Rosen and Smith 1983; Shilling et al. 1987; Wheaton and Torto 1988; Wheaton et al. 1997a). Subsequent studies have incorporated various demand and supply factors in explaining rent dynamics. For example, D'Arcy et al. (1999) present an investigation of the determinants of office rent in Dublin over a long sample period of 28 years in the period 1970-1997. The study shows that changes in real GDP and changes in the office stock are the most important drivers of changes in real office rents. Hendershott et al. (2002a) include supply and demand factors into their vacancy rate model and show that changes in real rents are related to changes in the demand and supply variables and the vacancy rate. Hendershott et al. (2002b) look into the retail and office property market in the U.K. covering eleven regions for 29 years, and they conclude that economic drivers such as income exert similar elasticities across regions and for both retail and office properties, with the exception of London. Hendershott et al. (2010) further examine the London office market by linking real rents with employment and supply of office space. Their results indicate an asymmetric rental adjustment, depending on the direction of the demand and supply shocks and the state of the market. Slade (2000) examines office rent determinants in distinct periods of a market cycle and shows that market participants value determinants of office rent differently during periods of decline, trough and recovery. De Francesco (2008) focuses on the demand-employment relationship in the context of rental adjustment mechanism for the major Australian central business district office markets, and he shows that an equilibrium exists between vacancy, rent, demand, and employment, and that other macroeconomic variables are found to be relevant cyclical determinants. Brounen and Jennen (2009) show that rents of ten European office markets respond to changes in economic activity, lagged rent changes, and the deviation from their long-run values at the national aggregate levels, but they find no evidence of improved explanatory power by including local market fundamentals. Ibanez and Pennington-Cross (2013) investigate commercial property rent dynamics for 34 large metropolitan areas in the U.S. across different property types and find office is the slowest to adjust back to its equilibrium in face of changing demand and supply conditions. Chau and Wong (2016) examine how information asymmetry affects rent adjustment using data from the Hong Kong office market. Their findings indicate that asymmetric information leads to slower rent adjustments in response to external shocks. Lastly, several studies examine the impact of crises on the housing market. For instance, Quigley (2001) shows that activities in the real estate markets were an important contributor to the financial crises of 1997 in the Asian economies. Agnello et al. (2017) show that financial crises are associated with increase in likelihood of the end of a housing boom. In the real estate equity market, Chiang et al. (2013) show that REITs are not as defensive as they are at times of financial crises when compared to times of stable markets.

\section{Sample Data and Descriptive Statistics}

\subsection{Sample Data}

Our analysis draws on proprietary real estate data from JLL, which provides the most current data on rents that is usually unavailable from public sources. Its database consists of quarterly data, covering a time period of approximately 10 years starting from the first quarter of 2010. Hence, our sample period includes quarterly observations from 2010 to the second quarter of 2020. Specifically, we obtain our rental and capital value data 
from JLL's Real Estate Intelligence Services (REIS), which is a subscription-based research service designed to provide timely real estate intelligence and analysis for property markets across the Asia-Pacific region. The information in REIS comes from data collected at the property level by the local teams in each respective market and is then rolled up to generate aggregated data at the market level. The basket of properties used to calculate property market indicators pertains primarily to Grade A or Prime Grade properties, and as such, the focus of this analysis is on such commercial properties. REIS provides a variety of different rent indicators, of which there are distinctive differences among them. For example, net rents pertain to face rents that have not taken into account tenant incentives such as rentfree period, while net effective rents are calculated after factoring in the effects of incentives. Rents may also be measured on a Gross Floor Area (GFA) basis, or a Net Lettable Area (NLA) basis. As the availability of rent indicators varies across markets and sectors, we utilize the closest rent definitions across for each market and sector. Moreover, for any given market and sector, the same rent indicator is used across time, so consistency is maintained. Similarly, we obtain the capital value measure from REIS, and we measure capital values by the definition of the implicit base price payable per square meter of area, where base price is estimated by industry convention as the current market rent divided by the market yield at the same point in time. The data in Appendix A include definitions of all variables used in this study.

Our data from JLL cover the commercial property markets of 38 cities in 12 countries and jurisdictions across the Asia-Pacific region, which give us extensive coverage of the commercial property market in the region that also represents a substantial proportion of the global market. Major tier 1 cities are included in the dataset, such as Singapore, Hong Kong and Tokyo. Tier 2 cities, such as Chengdu, Hyderabad and Kuala Lumpur, are also included. On a country level, the data include the economic powerhouses of China, Japan, and India, mature economies such as Australia and South Korea, and smaller developing nations such as those in Southeast Asia. Four property sectors are covered by JLL, and they are the office, retail, industrial and residential sectors. ${ }^{2}$ The retail sector pertains primarily to retail malls and shopping centers, and to regional centers in the case of Australia. The residential sector covers both luxury residential and prime residential properties. Industrial properties refer to distribution warehouses and logistics properties. Table 1 lists the cities and property type sectors that are covered by JLL and constitute the sample in this study.

Table 1. List of Cities and Property Sectors. This table presents the list of cities and property sectors covered by the study with data from JLL.

\begin{tabular}{ccccc}
\hline Cities & Office & Retail & Residential & Industrial \\
\hline Adelaide & $\sqrt{ }$ & $\sqrt{ }$ & & $\sqrt{ }$ \\
Bangalore & $\sqrt{ }$ & $\sqrt{ }$ & $\sqrt{ }$ & \\
Bangkok & $\sqrt{ }$ & $\sqrt{ }$ & $\sqrt{ }$ & $\sqrt{ }$ \\
Beijing & $\sqrt{ }$ & $\sqrt{ }$ & $\sqrt{ }$ \\
Brisbane & $\sqrt{ }$ & $\sqrt{ }$ & \\
Chengdu & $\sqrt{ }$ & $\sqrt{ }$ & $\sqrt{ }$ \\
Chennai & $\sqrt{ }$ & $\sqrt{ }$ & $\sqrt{ }$ \\
Chongqing & $\sqrt{ }$ & $\sqrt{ }$ & $\sqrt{ }$ \\
Delhi & $\sqrt{ }$ & $\sqrt{ }$ & $\sqrt{ }$ \\
Guangzhou & $\sqrt{ }$ & $\sqrt{ }$ & \\
Hangzhou & $\sqrt{ }$ & & $\sqrt{ }$ & \\
Hong Kong & $\sqrt{ }$ & $\sqrt{ }$ & $\sqrt{ }$ \\
Hyderabad & $\sqrt{ }$ & $\sqrt{ }$ & $\sqrt{ }$ & \\
Jakarta & $\sqrt{ }$ & $\sqrt{ }$ & $\sqrt{ }$ & \\
Kolkata & $\sqrt{ }$ & $\sqrt{ }$ & $\sqrt{ }$ & \\
Kuala Lumpur & $\sqrt{ }$ & & $\sqrt{ }$ & \\
Kunshan & & $\sqrt{ }$ & & \\
Macau & & & & \\
Manila & & $\sqrt{ }$ & & \\
\hline
\end{tabular}


Table 1. Cont.

\begin{tabular}{ccccc}
\hline Cities & Office & Retail & Residential & Industrial \\
\hline Melbourne & $\sqrt{ }$ & $\sqrt{ }$ & $\sqrt{ }$ \\
Mumbai & $\sqrt{ }$ & $\sqrt{ }$ & $\sqrt{ }$ \\
Nanjing & $\sqrt{ }$ & & \\
Osaka & $\sqrt{ }$ & $\sqrt{ }$ & $\sqrt{ }$ \\
Perth & $\sqrt{ }$ & $\sqrt{ }$ & \\
Pune & $\sqrt{ }$ & & $\sqrt{ }$ & \\
Qingdao & $\sqrt{ }$ & $\sqrt{ }$ & $\sqrt{ }$ \\
Seoul & $\sqrt{ }$ & $\sqrt{ }$ & $\sqrt{ }$ \\
Shanghai & $\sqrt{ }$ & & $\sqrt{ }$ \\
Shenyang & $\sqrt{ }$ & $\sqrt{ }$ & $\sqrt{ }$ \\
Shenzhen & $\sqrt{ }$ & & $\sqrt{ }$ \\
Singapore & $\sqrt{ }$ & $\sqrt{ }$ & $\sqrt{ }$ \\
Suzhou & $\sqrt{ }$ & & $\sqrt{ }$ \\
Sydney & $\sqrt{ }$ & & \\
Taipei & $\sqrt{ }$ & & \\
Tianjin & $\sqrt{ }$ & $\sqrt{ }$ & \\
Tokyo & $\sqrt{ }$ & $\sqrt{ }$ & & \\
Wuhan & $\sqrt{ }$ & & & \\
Xi'an & $\sqrt{ }$ & & & \\
\hline
\end{tabular}

Our test variable pertains to the impact of the COVID-19 pandemic on the commercial real estate market. Hence, we define the key variable COVID for observations since the onset of the COVID-19 pandemic in the first two quarters of 2020. We further classify the quarters into the first and second quarter, COVID_Q1 and COVID_Q2, respectively, since prior studies have documented substantial recovery in the stock market in the second quarter (e.g., Fahlenbrach et al. 2020; Hassan et al. 2020). Hence, it would be interesting to determine whether there exists any recovery in the commercial property market by the second quarter of 2020. In addition, we also assess the severity of the COVID-19 impact, measured as the total number of confirmed cases (COVID_CASE) or the number of deaths (COVID_DEATH) of the specific country or jurisdiction as of 30 June 2020. Data on COVID-19 are sourced from Our World in Data, a scientific online publication that focuses on large global problems such as poverty, disease, hunger, climate change, war, existential risks, and inequality. We obtain data for our macroeconomic control variables from Oxford Economics, an economics research and analytics consultancy firm providing services in global forecasting and quantitative analysis. These variables include GDP, measured on a per-capita basis in USD in real terms, the quarter-to-quarter percentage change in total population and unemployment rate, and population density. We also include the quarter-to-quarter percentage change in interest rate, with data obtained from Central Bank Policy. We obtain measures of fiscal stimuli from the United Nations' Economic and Social Commission for Asia and the Pacific (ESCAP) (United Nations 2020).

\subsection{Descriptive Statistics}

Our total sample has 3990 quarterly observations across the 38 cities and four different property types over the sample period. Table 2 presents the descriptive statistics of the variables used in the empirical analysis. RENT has an annualized mean of $\$ 414.8$ USD per square meter, and average CAPITAL VALUE is $\$ 7141.1$ USD per square meter. By construction, $4.8 \%$ of the sample observations belong to the COVID-19 period. GDP percapita in the Asia-Pacific region has a mean of \$6398.8 USD. Population has, on average, been growing modestly over the sample period at $0.22 \%$ per quarter. Percentage change on unemployment rate has an average of $3.306 \%$. However, the median is merely $0.256 \%$. The percentage quarterly change on interest rate has an average of $-1.207 \%$ over the sample period across the region. Population density is at an average of 843.7 people per square kilometer. The numbers of the COVID-19 total confirmed cases and deaths, averaged per city and per quarter over the whole sample period, have means of 0.038 and 0.001 . The 
corresponding average numbers of new cases and new deaths, per city and per quarter, are 0.030 and $0.001 .^{3}$ The average fiscal stimulus across the countries and jurisdictions over the whole sample period is $\$ 18,293$ million USD. ${ }^{4}$ Lastly, the percentages of office, retail, residential, and industrial observations in the sample are $37.9 \%, 26.3 \%, 14.7 \%$, and 21.1\%, respectively.

Table 2. Descriptive Statistics. This table provides descriptive statistics for the sample observations of the variables used in the empirical tests. Variable definitions are provided in Appendix A.

\begin{tabular}{lcccccc}
\hline \multicolumn{1}{c}{ Variables } & N & Mean & Median & P25 & P75 & Std. Dev \\
\hline RENT & 3990 & 414.8 & 232.0 & 118.0 & 509.0 & 478.4 \\
CAPITAL_VALUE & 3948 & 7141.1 & 3970.5 & 1769 & 8235.5 & 9521.2 \\
COVID & 3990 & 0.048 & 0.000 & 0.000 & 0.000 & 0.213 \\
COVID_Q1 & 3990 & 0.024 & 0.000 & 0.000 & 0.000 & 0.152 \\
COVID_Q2 & 3990 & 0.024 & 0.000 & 0.000 & 0.000 & 0.152 \\
GDP & 3990 & 6398.8 & 3832.8 & 2642.1 & $11,399.5$ & 5478.6 \\
POPULATION_CHG & 3990 & 0.220 & 0.145 & 0.125 & 0.320 & 0.131 \\
UNEMPLOYMENT_CHG & 3990 & 3.306 & 0.256 & -1.403 & 2.811 & 22.965 \\
INTEREST_CHG & 3990 & -1.207 & 0.000 & -2.915 & 0.521 & 11.669 \\
POPULATION_DEN & 3990 & 843.7 & 144.4 & 134.8 & 403.5 & 2041.7 \\
COVID_CASE & 3990 & 0.038 & 0.000 & 0.000 & 0.000 & 0.354 \\
COVID_DEATH & 3990 & 0.001 & 0.000 & 0.000 & 0.000 & 0.011 \\
NEW_CASE & 3990 & 0.030 & 0.000 & 0.000 & 0.000 & 0.344 \\
NEW_DEATH & 3990 & 0.001 & 0.000 & 0.000 & 0.000 & 0.011 \\
FISCAL & 3990 & 18,293 & 0.000 & 0.000 & 0.000 & 113,011 \\
OFFICE & 3990 & 0.379 & 0.000 & 0.000 & 1.000 & 0.485 \\
RETAIL & 3990 & 0.263 & 0.000 & 0.000 & 1.000 & 0.440 \\
RESIDENTIAL & 3990 & 0.147 & 0.000 & 0.000 & 0.000 & 0.355 \\
INDUSTRIAL & 3990 & 0.211 & 0.000 & 0.000 & 0.000 & 0.408 \\
\hline
\end{tabular}

\section{Main Empirical Analysis}

\subsection{Research Design}

To examine the impact of COVID-19 on rent, we adopt a multivariate regression approach, controlling for different macroeconomic fundamentals and city and property type fixed effects (e.g., Ling et al. 2020). Specifically, we run OLS regression analysis with the following specifications:

$$
\begin{gathered}
\text { LOG }(\text { RENT })=\alpha+\beta_{1} \text { COVID }+\beta_{2} \text { LOG }(G D P)+\beta_{3} \text { POPULATION_CHG }+ \\
\beta_{4} \text { UNEMPLOYMENT_CHG }+\beta_{5} \text { INTEREST_CHG }+\beta_{6} \text { POPULATION_DEN }+ \\
\text { CITY EFFECTS }+ \text { PROPERTYTYPE EFFECTS }+\varepsilon \\
\text { LOG }(\text { RENT })=\alpha+\beta_{11} \text { COVID_Q } 1+\beta_{12} \text { COVID_Q } 2+\beta_{2} L O G(G D P)+ \\
\beta_{3} \text { POPULATION_CHG }+\beta_{4} \text { UNEMPLOYMENT_CHG }+\beta_{5} I N T E R E S T \_C H G+ \\
\beta_{6} \text { POPULATION_DEN }+ \text { CITY EFFECTS }+ \text { PROPERTYTYPE EFFECTS }+\varepsilon
\end{gathered}
$$

where LOG (RENT) represents the natural logarithm of average rent for a specific market and property sector. Our variable of interest in (1) is COVID, the first two quarters in 2020 under the COVID-19 pandemic. We further classify the period into the first (COVID_Q1) and second (COVID_Q2) quarters in (2) to examine whether there exists any early recovery in the Asia-Pacific commercial property market in the second quarter of 2020. We include the natural logarithm form of GDP, POPULATION_CHG, UNEMPLOYMENT_CHG, INTEREST_CHG, and POPULATION_DEN as macroeconomic controls (e.g., Adams and Füss 2010; Baffoe-Bonnie 1998; Edelstein and Tsang 2007). Lastly, as the commercial property market is substantially different across the Asia-Pacific region (Eichholtz et al. 1998) and property sectors (Archer and Ling 2012), we control for city and property type effects in all regressions. 
We next examine how the severity of the COVID-19 pandemic affects the commercial property market. As mentioned, the impact of the pandemic varies across the Asia-Pacific region. While some countries, such as India, reported explosive outbreaks in the midst of the pandemic, other places, such as China, Hong Kong, and Singapore, seemed to be more effective in mitigating the spread of the virus through effective policy interventions. We measure the severity of the COVID-19 pandemic in different regions by the number of confirmed cases and deaths as of 30 June 2020, and we test the following specifications:

$$
\begin{gathered}
\text { LOG }(\text { RENT })=\alpha+\beta_{1} \text { COVID_CASE }+\beta_{2} L O G(G D P)+\beta_{3} \text { POPULATION_CHG }+ \\
\beta_{4} \text { UNEMPLOYMENT_CHG }+\beta_{5} \text { INTEREST_CHG }+ \\
\beta_{6} \text { POPULATION_DEN }+ \text { CITY EFFECTS }+ \text { PROPERTYTYPE EFFECTS }+\varepsilon \\
\text { LOG }(R E N T)=\alpha+\beta_{1} \text { COVID_DEATH }+\beta_{2} L O G(G D P)+ \\
\beta_{3} \text { POPULATION_CHG }+\beta_{4} \text { UNEMPLOYMENT_CHG }+\beta_{5} \text { INTEREST_CHG }+ \\
\beta_{6} \text { POPULATION_DEN }+ \text { CITY EFFECTS }+ \text { PROPERTY TYPE EFFECTS }+\varepsilon
\end{gathered}
$$

Lastly, we examine how the COVID-19 pandemic affects different property sectors. Anecdotal evidence has shown that the retail sector, especially brick-and-mortar stores, took a huge hit during the pandemic (e.g., OECD 2020a). Hence, we hypothesize that the pandemic exerts a substantial negative impact on rents for retail properties. Nonetheless, the imposition of social distancing and remote work measures in many regions could also have weakened the demand for office properties. Additionally, the impact of the current pandemic is far fetched and widespread, which could make the other property sectors also susceptible to downward pressure on rent due to re-negotiations. On the other hand, investors could be reallocating funds to more resilient sectors such as the industrial or residential sectors (Gilchrist 2020). To examine the impact of the COVID-19 pandemic on different property sectors, we augment models (1) and (2) by including the interaction terms of the COVID-19 variables with the property type dummies:

$$
\begin{aligned}
& \text { LOG }(\text { RENT })=\beta_{1 A} \text { COVID } * \text { OFFICE }+\beta_{1 B} \text { COVID }{ }^{*} \text { RETAIL }+ \\
& \beta_{1 C} \text { COVID }{ }^{*} \text { ESIDENTIAL }+\beta_{1 D} \text { COVID*INDUSTRIAL }+\beta_{2} \text { LOG }(G D P)+ \\
& \beta_{3} \text { POPULATION_CHG }+\beta_{4} \text { UNEMPLOYMENT_CHG }+\beta_{5} \text { INTEREST_CHG }+ \\
& \beta_{6} \text { POPULATION_DEN + CITY EFFECTS }+ \text { PROPERTY TYPE EFFECTS }+\varepsilon \\
& L O G(R E N T)=\beta_{11 A} \text { COVID_Q1*OFFICE }+\beta_{11 B} \text { COVID_Q1*RETAIL }+ \\
& \beta_{11 C} \text { COVID_Q1*RESIDENTIAL }+\beta_{11 D} \text { COVID_Q1*INDUSTRIAL + } \\
& \beta_{12 A} \text { COVID_Q2 }{ }^{*} \text { OFFICE }+\beta_{12 B} \text { COVID_Q2*RETAIL }+ \\
& \beta_{12 C} \text { COVID_Q2*RESIDENTIAL }+\beta_{12 D} \text { COVID_Q2*INDUSTRIAL + } \\
& \beta_{2} \text { LOG }(G D P)+\beta_{3} \text { POPULATION_CHG }+\beta_{4} \text { UNEMPLOYMENT_CHG + } \\
& \beta_{5} \text { INTEREST_CHG }+\beta_{6} \text { POPULATION_DEN + CITY EFFECTS + } \\
& \text { PROPERTY TYPE EFFECTS }+\varepsilon
\end{aligned}
$$

\subsection{Empirical Findings}

Table 3 presents the empirical results of specifications (1) and (2), with the first and third columns showing the sole impact of the COVID-19 variables, and the second and fourth columns with the macroeconomic control variables. In column I, we observe that the coefficient of COVID is highly significant and negative (at the $1 \%$ level), indicating that the COVID-19 pandemic has exerted a significantly negative impact on market rent in the Asia-Pacific region. Economically, the coefficient of -0.0727 implies a quarterly decline of $7.27 \%$ of $\log$ market rent in the first two quarters of 2020 in the midst of the pandemic. We also obtain a negative and significant coefficient (at the 1\% level) for COVID in column II with the inclusion of control variables, and the coefficient of -0.0709 translates into a per-quarter rent decline of $7.09 \%$. For the controls, we show that GDP and population change both have positive and significant impacts on market rent. 
Table 3. The Impact of the COVID-19 Pandemic on Rent Dynamics. This table presents the OLS regression estimation results of testing the impact of the COVID-19 pandemic on commercial real estate rent. The dependent variable is LOG (RENT), the natural logarithm of rent for the specific city and property type. The independent variables of interest are COVID, COVID_Q1 and COVID_Q2. All variables are described in Appendix A. The standard errors are reported in parentheses. $* * *, * *$, and ${ }^{*}$ denote significance of the $t$-statistics at the $<1 \%, 5 \%$ and $10 \%$ levels, respectively.

\begin{tabular}{|c|c|c|c|c|}
\hline Variables & $\mathbf{I}$ & II & III & IV \\
\hline COVID & $\begin{array}{c}-0.0727^{* * *} \\
(0.0195)\end{array}$ & $\begin{array}{c}-0.0709^{* * *} \\
(0.0237)\end{array}$ & & \\
\hline COVID_Q1 & & & $\begin{array}{c}-0.0780^{* * *} \\
(0.02719)\end{array}$ & $\begin{array}{c}-0.0923^{* * *} \\
(0.0326)\end{array}$ \\
\hline COVID_Q2 & & & $\begin{array}{c}-0.0675^{* *} \\
(0.02719)\end{array}$ & $\begin{array}{c}-0.0538^{*} \\
(0.0297)\end{array}$ \\
\hline$L O G(G D P)$ & & $\begin{array}{c}0.1382 * * * \\
(0.0275)\end{array}$ & & $\begin{array}{c}0.1392^{* * *} \\
(0.0275)\end{array}$ \\
\hline POPULATION_CHG & & $\begin{array}{c}0.5024^{* * *} \\
(0.0846)\end{array}$ & & $\begin{array}{c}0.5027 * * * \\
(0.0846)\end{array}$ \\
\hline UNEMPLOYMENT_CHG & & $\begin{array}{c}0.0003 \\
(0.0002)\end{array}$ & & $\begin{array}{c}0.0003 \\
(0.0002)\end{array}$ \\
\hline INTEREST_CHG & & $\begin{array}{c}0.0005 \\
(0.0004)\end{array}$ & & $\begin{array}{c}0.0005 \\
(0.0004)\end{array}$ \\
\hline POPULATION_DEN & & $\begin{array}{c}0.0000 \\
(0.0000)\end{array}$ & & $\begin{array}{c}0.0000 \\
(0.0000)\end{array}$ \\
\hline Constant & $\begin{array}{c}3.3357^{* * *} \\
(0.0308) \\
\end{array}$ & $\begin{array}{c}2.1783 * * * \\
(0.2105)\end{array}$ & $\begin{array}{c}3.3357 * * * \\
(0.0309)\end{array}$ & $\begin{array}{c}2.1714^{* * *} \\
(0.2106)\end{array}$ \\
\hline City Dummies & Yes & Yes & Yes & Yes \\
\hline Property Type Dummies & Yes & Yes & Yes & Yes \\
\hline Adjusted $\mathrm{R}^{2}$ & 0.9341 & 0.9348 & 0.9340 & 0.9348 \\
\hline Observations & 3990 & 3990 & 3990 & 3990 \\
\hline
\end{tabular}

In column III, we further examine the differential impact of the first and second quarters of 2020. We find that the coefficients are both negative and significant (at the $1 \%$ and $5 \%$ levels, respectively), but their differences are statistically insignificant (t-statistics $=0.0021$ ). The results imply that, contrasting to studies that document the recovery of the stock market (Fahlenbrach et al. 2020; Hassan et al. 2020), the negative impact on the commercial property market persists and the commercial property market is slower and has yet to recover by the middle of 2020. We obtain similar findings in column IV with the inclusion of the control variables, though the coefficient of COVID_Q2 has become substantially smaller in magnitude (-0.0538) and is only marginally significant (at the $10 \%$ level). Overall, the economic impact of the COVID-19 pandemic on commercial property rent amounts to $14.55 \%$ and $14.61 \%$ in columns III and IV, respectively.

In Table 4, we report empirical results of specifications (3) and (4). The first (last) two columns report results with COVID_CASE (COVID_DEATH) as our variable of interest. In all columns, we find that the coefficients of interest are negative and significant (at the $5 \%$ level). The findings show that the commercial property market is adversely affected by the severity of the COVID-19 pandemic. In general, for regions with higher confirmed cases and deaths, we observe more significant declines in market rent. These findings provide additional corroborating evidence that the declines in market rents in the commercial property market is related to the severity of the COVID-19 pandemic.

We next report, in Table 5, the empirical results of specifications (5) and (6), for which we examine the impact of the COVID-19 pandemic on different property sectors. In the first two columns (I and II), we show that the pandemic has a prominent impact on both the office and retail sectors, as the coefficients of the interactions terms of COVID and these property type dummies are negative and significant (at the $5 \%$ level for office and $1 \%$ level for retail). Economically, the coefficients translate into an estimated $14 \%$ drop in market rent for office properties and approximately a 31\% drop for retail properties in the first 
six months of 2020. However, some interesting patterns have emerged when we further classify the COVID-19 period into the first and second quarters with results reported in the last two columns (III and IV). While we find the negative trend for rent in the retail property sector remains throughout the second quarter of 2020, the negative coefficients of COVID_Q2 are no longer significant for the office property sector. These findings provide some indications that the office sector could be recovering, or at least not dropping further, by the second quarter of 2020. We do not find market rent being significantly impacted by the pandemic for other property sectors.

Table 4. The Impact of the COVID-19 Pandemic on Rent Dynamics by Cases and Deaths. This table presents the OLS regression estimation results of testing the impact of the COVID-19 pandemic on commercial real estate rent. The dependent variable is $L O G$ (RENT), the natural logarithm of rent for the specific city and property type. The independent variables of interest are COVID_CASE, and COVID_DEATH, which represent the total cumulative COVID-19 confirmed cases and deaths by country/jurisdiction, respectively. All variables are described in Appendix A. The standard errors are reported in parentheses. ${ }^{* * *},{ }^{* *}$, and $*$ denote significance of the $\mathrm{t}$-statistics at the $<1 \%, 5 \%$ and $10 \%$ levels, respectively.

\begin{tabular}{|c|c|c|c|c|}
\hline Variables & I & II & III & IV \\
\hline COVID_CASE & $\begin{array}{c}-0.0290 \text { ** } \\
(0.0118)\end{array}$ & $\begin{array}{c}-0.0276^{* *} \\
(0.013)\end{array}$ & & \\
\hline COVID_DEATH & & & $\begin{array}{c}-0.8624^{* *} \\
(0.3665)\end{array}$ & $\begin{array}{c}-0.8573^{* *} \\
(0.3990)\end{array}$ \\
\hline$L O G(G D P)$ & & $\begin{array}{c}0.1335^{* * *} \\
(0.0274)\end{array}$ & & $\begin{array}{c}0.1353^{* * * *} \\
(0.0275)\end{array}$ \\
\hline POPULATION_CHG & & $\begin{array}{c}0.5235^{* * *} \\
(0.0843)\end{array}$ & & $\begin{array}{c}0.5223^{* * * *} \\
(0.0843)\end{array}$ \\
\hline UNEMPLOYMENT_CHG & & $\begin{array}{c}0.0001 \\
(0.0002)\end{array}$ & & $\begin{array}{c}0.0001 \\
(0.0002)\end{array}$ \\
\hline INTEREST_CHG & & $\begin{array}{l}0.0007^{*} \\
(0.0004)\end{array}$ & & $\begin{array}{l}0.0007^{*} \\
(0.0004)\end{array}$ \\
\hline POPULATION_DEN & & $\begin{array}{c}0.0000 \\
(0.0000)\end{array}$ & & $\begin{array}{c}0.0000 \\
(0.0000)\end{array}$ \\
\hline Constant & $\begin{array}{c}3.3362 * * * \\
(0.0309)\end{array}$ & $\begin{array}{c}2.2135^{* * *} \\
(0.2100)\end{array}$ & $\begin{array}{c}3.3357^{* * *} \\
(0.0309)\end{array}$ & $\begin{array}{c}2.2011^{* * *} \\
(0.2104)\end{array}$ \\
\hline City Dummies & Yes & Yes & Yes & Yes \\
\hline Property Type Dummies & Yes & Yes & Yes & Yes \\
\hline Adjusted $\mathrm{R}^{2}$ & 0.9339 & 0.9348 & 0.9339 & 0.9348 \\
\hline Observations & 3990 & 3990 & 3990 & 3990 \\
\hline
\end{tabular}

Table 5. The Impact of the COVID-19 Pandemic on Rent Dynamics by Property Types. This table presents the OLS regression estimation results of testing the impact of the COVID-19 pandemic on commercial real estate rent. The dependent variable is LOG (RENT), the natural logarithm of rent for the specific city and property type. The independent variables of interest are the interaction terms of COVID, COVID_Q1 and COVID_Q2 with the property type dummies. All variables are described in Appendix A. The standard errors are reported in parentheses. ${ }^{* *},{ }^{* *}$, and ${ }^{*}$ denote significance of the $\mathrm{t}$-statistics at the $<1 \%$, $5 \%$ and $10 \%$ levels, respectively.

\begin{tabular}{|c|c|c|c|c|}
\hline Variables & I & II & III & IV \\
\hline COVID ${ }^{*}$ OFFICE & $\begin{array}{c}-0.0701 \text { ** } \\
(0.0316)\end{array}$ & $\begin{array}{c}-0.0694^{* *} \\
(0.0340)\end{array}$ & & \\
\hline COVID*RETAIL & $\begin{array}{c}-0.1579 * * * \\
(0.0379)\end{array}$ & $\begin{array}{c}-0.1525^{* * *} \\
(0.0401)\end{array}$ & & \\
\hline COVID*RESIDENTIAL & $\begin{array}{l}-0.0055 \\
(0.0506)\end{array}$ & $\begin{array}{l}-0.0079 \\
(0.0530)\end{array}$ & & \\
\hline COVID*INDUSTRIAL & $\begin{array}{l}-0.0180 \\
(0.0424)\end{array}$ & $\begin{array}{l}-0.0123 \\
(0.0443)\end{array}$ & & \\
\hline COVID_Q1*OFFICE & & & $\begin{array}{c}-0.0742 * \\
(0.0441)\end{array}$ & $\begin{array}{c}-0.0908 * \\
(0.0475)\end{array}$ \\
\hline COVID_Q1*RETAIL & & & $\begin{array}{c}-0.1576^{* * *} \\
(0.0530)\end{array}$ & $\begin{aligned}- & 0.1670 \text { *** } \\
& (0.0544)\end{aligned}$ \\
\hline
\end{tabular}


Table 5. Cont.

\begin{tabular}{lcccc}
\hline \multicolumn{1}{c}{ Variables } & I & II & III & IV \\
\hline COVID_Q1*RESIDENTIAL & & & -0.0092 & -0.0238 \\
& & & $(0.0708)$ & $(0.0727)$ \\
COVID_Q1*INDUSTRIAL & & -0.0333 & -0.0555 \\
COVID_Q2*IFFICE & & $(0.0592)$ & $(0.0649)$ \\
& & -0.0661 & -0.0555 \\
COVID_Q2*RETAIL & & $(0.0441)$ & $(0.0453)$ \\
& & $-0.1582^{* * *}$ & $-0.1446^{* * * *}$ \\
COVID_Q2*RESIDENTIAL & & $(0.0530)$ & $(0.0551)$ \\
& & -0.0017 & -0.0010 \\
COVID_Q2*INDUSTRIAL & & $(0.0708)$ & $(0.0723)$ \\
& Yes & -0.0027 & 0.0232 \\
City Dummies & Yes & & $(0.0592)$ & $(0.0600)$ \\
Property Type Dummies & No & Yes & Yes \\
Macroeconomic Controls & 0.9341 & Yes & Yes & Yes \\
Adjusted R & 3990 & Yes & No & Yes \\
Observations & & 0.9349 & 0.9341 & 0.9349 \\
\hline
\end{tabular}

\section{Additional and Robustness Analysis}

\subsection{Additional Analysis on Capital Values}

In an additional analysis, we also examine capital values. While rent might serve as a more immediate signal of market demand, capital values incorporate market expectation. We replace our dependent variable RENT with CAPITAL_VALUE in our regression analysis. We re-run our empirical specifications (1) and (2) and report the results in Table 6, Panel A. In column I, we show that the coefficient of COVID is marginally significant (at the $10 \%$ level), but of the wrong sign. More importantly, we find that none of the other COVID-19 variables has the expected significant negative coefficients on capital values in all columns. ${ }^{5}$ At first glance, it seems that the market perceives the impact of the pandemic crisis to be short lived and the decline in market rent does not translate into a substantial dip in capital values.

It is intriguing why capital values are almost unaffected by the pandemic while rents fall substantially. Of course, one of the possibilities could be due to the delayed reaction in private commercial property prices (Van Dijk et al. 2020). However, the findings could also be explained by the varied responses to the COVID-19 pandemic in different property sectors. Empirical results presented in Panel B of Table 6, which we examine the impact of the COVID-19 pandemic on capital values of different property types, may offer some insights of the latter. In the first two columns (I and II), we observe that the COVID variable has exerted significant negative impact (at the $1 \%$ level) on capital values for the retail property sector. However, we also observe that the coefficients of COVID interacting with the residential and industrial sectors are positive and significant (in column I and in both columns, respectively). This finding is interesting. It shows that capital values have fallen for retail properties in the midst of the COVID-19 pandemic, but those falls are at least partially offset by the increases in the residential and especially the industrial sectors. These results may explain why capital values remain unaffected for the overall commercial property market during the pandemic. The finding may indicate a reshuffling of capital from the retail to the residential and industrial sectors. The phenomenon is similar to a flight to quality observed during the financial crisis: Devos et al. (2013) show that REIT institutional investors flocked to the REIT market for a safe harbor by increasing ownership in larger REITs. Similarly, in light of the COVID-19 pandemic, commercial property market participants could be reattributing their investments from the retail to the other sectors when the risk of the retail property market is deemed to be too high and the recovery of the market has too much uncertainty. We obtain similar findings in the last two 
columns (III and IV) of Panel B, where we divide the COVID-19 period into the first and second quarters.

Table 6. Additional Analysis on Capital Values. This table presents the OLS regression estimation results of testing the impact of the COVID-19 pandemic on commercial real estate capital values. The dependent variable is LOG (CAPITAL_VALUE), the natural logarithm of capital value for the specific city and property type. In Panel A, the independent variables of interest are COVID, COVID_Q1 and COVID_Q2. In Panel B, the independent variables of interest are the interaction terms of COVID,COVID_Q1 and COVID_Q2 with the property type dummies. All variables are described in Appendix A. The standard errors are reported in parentheses. ${ }^{* * *},{ }^{* *}$, and ${ }^{*}$ denote significance of the $\mathrm{t}$-statistics at the $<1 \%, 5 \%$ and $10 \%$ levels, respectively.

\begin{tabular}{|c|c|c|c|c|}
\hline \multicolumn{5}{|c|}{ Panel A: The Impact of the COVID-19 Pandemic on Capital Values } \\
\hline Variables & I & II & III & IV \\
\hline COVID & $\begin{array}{l}0.0371 * \\
(0.0202)\end{array}$ & $\begin{array}{l}-0.0111 \\
(0.0242)\end{array}$ & & \\
\hline COVID_Q1 & & & $\begin{array}{c}0.0300 \\
(0.0282)\end{array}$ & $\begin{array}{c}-0.0232 \\
(0.0334)\end{array}$ \\
\hline COVID_Q2 & & & $\begin{array}{c}0.0443 \\
(0.0282)\end{array}$ & $\begin{array}{l}-0.0016 \\
(0.0302)\end{array}$ \\
\hline$L O G(G D P)$ & & $\begin{array}{c}0.3533 * * * \\
(0.0279)\end{array}$ & & $\begin{array}{c}0.3538 * * * \\
(0.0279)\end{array}$ \\
\hline POPULATION_CHG & & $\begin{array}{c}0.3910^{* * *} \\
(0.0858)\end{array}$ & & $\begin{array}{c}0.3912 * * * \\
(0.0858)\end{array}$ \\
\hline UNEMPLOYMENT_CHG & & $\begin{array}{c}0.0003 \\
(0.0002)\end{array}$ & & $\begin{array}{c}0.0003 \\
(0.0002)\end{array}$ \\
\hline INTEREST_CHG & & $\begin{array}{l}-0.0004 \\
(0.0004)\end{array}$ & & $\begin{array}{c}-0.0003 \\
(0.0003)\end{array}$ \\
\hline POPULATION_DEN & & $\begin{array}{c}0.0002 * * * \\
(0.0001)\end{array}$ & & $\begin{array}{c}0.0002 * * * \\
(0.0001)\end{array}$ \\
\hline Constant & $\begin{array}{c}5.5678^{* * *} \\
(0.0318)\end{array}$ & $\begin{array}{c}2.7716^{* * *} \\
(0.2136)\end{array}$ & $\begin{array}{c}5.5678 * * * \\
(0.0318)\end{array}$ & $\begin{array}{c}2.7678^{* * *} \\
(0.2137)\end{array}$ \\
\hline City Dummies & Yes & Yes & Yes & Yes \\
\hline Property Type Dummies & Yes & Yes & Yes & Yes \\
\hline Adjusted $\mathrm{R}^{2}$ & 0.9423 & 0.9449 & 0.9423 & 0.9449 \\
\hline Observations & 3948 & 3948 & 3948 & 3948 \\
\hline \multicolumn{5}{|c|}{ Panel B: The Impact of the COVID-19 Pandemic on Capital Values by Property Types } \\
\hline Variables & I & II & III & IV \\
\hline COVID*OFFICE & $\begin{array}{c}0.0437 \\
(0.0325)\end{array}$ & $\begin{array}{l}-0.0013 \\
(0.0344)\end{array}$ & & \\
\hline COVID*RETAIL & $\begin{array}{c}-0.1159 * * * \\
(0.0390)\end{array}$ & $\begin{array}{c}-0.1623^{* * *} \\
(0.0406)\end{array}$ & & \\
\hline COVID*RESIDENTIAL & $\begin{array}{c}0.1488 * * * \\
(0.0540)\end{array}$ & $\begin{array}{c}0.0851 \\
(0.0553)\end{array}$ & & \\
\hline COVID*INDUSTRIAL & $\begin{array}{c}0.1440^{* * *} \\
(0.0436)\end{array}$ & $\begin{array}{l}0.1011^{* *} \\
(0.0448)\end{array}$ & & \\
\hline COVID_Q1*OFFICE & & & $\begin{array}{c}0.0379 \\
(0.0454)\end{array}$ & $\begin{array}{l}-0.0128 \\
(0.0481)\end{array}$ \\
\hline COVID_Q1*RETAIL & & & $\begin{array}{c}-0.1146^{* *} \\
(0.0545)\end{array}$ & $\begin{array}{c}-0.1672 \text { *** } \\
(0.0551)\end{array}$ \\
\hline COVID_Q1*RESIDENTIAL & & & $\begin{array}{l}0.1333 * \\
(0.0755)\end{array}$ & $\begin{array}{c}0.0678 \\
(0.0765)\end{array}$ \\
\hline COVID_Q1*INDUSTRIAL & & & $\begin{array}{l}0.1291 * * \\
(0.0609)\end{array}$ & $\begin{array}{c}0.0827 \\
(0.0658)\end{array}$ \\
\hline COVID_Q2*OFFICE & & & $\begin{array}{c}0.0495 \\
(0.0454)\end{array}$ & $\begin{array}{c}0.0064 \\
(0.0458)\end{array}$ \\
\hline COVID_Q2*RETAIL & & & $\begin{array}{c}-0.11722^{* *} \\
(0.0545)\end{array}$ & $\begin{array}{c}-0.1607 * * * \\
(0.0557)\end{array}$ \\
\hline COVID_Q2*RESIDENTIAL & & & $\begin{array}{l}0.1644^{* *} \\
(0.0755)\end{array}$ & $\begin{array}{c}0.0980 \\
(0.0754)\end{array}$ \\
\hline COVID_Q2*INDUSTRIAL & & & $\begin{array}{c}0.1589 * * * \\
(0.0609)\end{array}$ & $\begin{array}{l}0.1158 * \\
(0.0607)\end{array}$ \\
\hline City Dummies & Yes & Yes & Yes & Yes \\
\hline Property Type Dummies & Yes & Yes & Yes & Yes \\
\hline Macroeconomic Controls & No & Yes & No & Yes \\
\hline Adjusted $\mathrm{R}^{2}$ & 0.9426 & 0.9452 & 0.9426 & 0.9451 \\
\hline Observations & 3948 & 3948 & 3948 & 3948 \\
\hline
\end{tabular}




\subsection{Additional Analysis on Government Policy Responses}

We next examine the moderating effect of government policy responses to the COVID19 crisis on the commercial property market. Given the unprecedented health crisis and its impact on the economy, many countries and jurisdictions have announced various government policies in response to the pandemic, hoping to minimize the negative financial impact brought on by the COVID-19 pandemic. One notable policy by most Asia-Pacific countries or jurisdictions is the announcement of fiscal stimuli packages. We obtain from United Nations' ESCAP detailed summaries on the fiscal stimuli packages for each country and jurisdiction in the Asia-Pacific region amid the pandemic, ${ }^{6}$ and we quantify these stimuli into the variable FISCAL, expressed in USD and now scaled by the country's or jurisdiction's annual GDP given their size differences. ${ }^{7}$ We augment our empirical specification (1) with the additional interaction term of COVID and FISCAL to capture the moderating effect of the imposition of the fiscal stimuli by the country or jurisdiction on the commercial property market. We report the results in columns I to III of Table 7 . In column I, we show that while the coefficient of COVID remains negative and significant (at the $1 \%$ level), the interaction term of COVID and FISCAL is positive and significant (also at the $1 \%$ level). The result indicates that governments' fiscal stimuli exert a positive impact on moderating the negative impact of the COVID-19 pandemic on the commercial property market. We continue to find a similar effect of the fiscal stimuli in columns II and III when we include macroeconomic control variables in regression specification (1). ${ }^{8}$

Table 7. Additional Analysis on Government Policy Responses. This table presents the OLS regression estimation results of testing the impact of the COVID-19 pandemic and government policy responses on commercial real estate rent. The dependent variable is $L O G$ (RENT), the natural logarithm of rent for the specific city and property type. The independent variables of interest are the interaction terms of COVID (COVID_Q2) and FISCAL. All variables are described in Appendix A. The standard errors are reported in parentheses. ${ }^{* * *}, * *$, and ${ }^{*}$ denote significance of the $\mathrm{t}$-statistics at the $<1 \%, 5 \%$ and $10 \%$ levels, respectively.

\begin{tabular}{|c|c|c|c|c|c|c|}
\hline Variables & I & II & III & IV & $\mathbf{V}$ & VI \\
\hline COVID*FISCAL & $\begin{array}{c}0.0155^{* * *} \\
(0.0054)\end{array}$ & $\begin{array}{c}0.0146^{* * *} \\
(0.0057)\end{array}$ & $\begin{array}{l}0.0123 * * \\
(0.0057)\end{array}$ & & & \\
\hline COVID_Q2*FISCAL & & & & $\begin{array}{l}0.0130 * \\
(0.0076)\end{array}$ & $\begin{array}{l}0.0163 * \\
(0.0086)\end{array}$ & $\begin{array}{c}0.0128 \\
(0.0086)\end{array}$ \\
\hline COVID & $\begin{array}{c}-0.1323 * * * \\
(0.0285)\end{array}$ & $\begin{array}{c}-0.1176^{* * *} \\
(0.0329)\end{array}$ & $\begin{array}{c}-0.1199 * * * \\
(0.0328)\end{array}$ & & & \\
\hline COVID_Q1 & & & & $\begin{array}{c}-0.0780 * * * \\
(0.0272)\end{array}$ & $\begin{array}{c}-0.0907^{* * *} \\
(0.0335)\end{array}$ & $\begin{array}{c}-0.1036^{* * *} \\
(0.0335)\end{array}$ \\
\hline COVID_Q2 & & & & $\begin{array}{c}-0.1175^{* * *} \\
(0.0399)\end{array}$ & $\begin{array}{c}-0.1186^{* *} \\
(0.0490)\end{array}$ & $\begin{array}{c}-0.1117^{* *} \\
(0.0488)\end{array}$ \\
\hline LOG (GDP) & & & $\begin{array}{c}0.1330^{* * *} \\
(0.0276)\end{array}$ & & & $\begin{array}{c}0.1357^{* * *} \\
(0.0276)\end{array}$ \\
\hline POPULATION_CHG & & $\begin{array}{c}0.4123^{* * *} \\
(0.0828)\end{array}$ & $\begin{array}{c}0.5016^{* * *} \\
(0.0846)\end{array}$ & & $\begin{array}{c}0.4097^{* * *} \\
(0.0828)\end{array}$ & $\begin{array}{c}0.5011^{* * *} \\
(0.0846)\end{array}$ \\
\hline UNEMPLOYMENT_CHG & & $\begin{array}{c}0.0001 \\
(0.0002)\end{array}$ & $\begin{array}{c}0.0002 \\
(0.0002)\end{array}$ & & $\begin{array}{c}0.0004 \\
(0.0002)\end{array}$ & $\begin{array}{l}0.0005 * \\
(0.0002)\end{array}$ \\
\hline INTEREST_CHG & & $\begin{array}{c}0.0001 \\
(0.0004)\end{array}$ & $\begin{array}{c}0.0002 \\
(0.0003)\end{array}$ & & $\begin{array}{c}0.0002 \\
(0.0004)\end{array}$ & $\begin{array}{c}0.0003 \\
(0.0004)\end{array}$ \\
\hline POPULATION_DEN & & $\begin{array}{c}0.0000 \\
(0.0001)\end{array}$ & $\begin{array}{c}0.0000 \\
(0.0000)\end{array}$ & & $\begin{array}{c}0.0000 \\
(0.0000)\end{array}$ & $\begin{array}{c}0.0000 \\
(0.0000)\end{array}$ \\
\hline Constant & $\begin{array}{c}3.3366^{* * *} \\
(0.0308)\end{array}$ & $\begin{array}{c}3.2000^{* * *} \\
(0.0329)\end{array}$ & $\begin{array}{c}2.2100^{* * *} \\
(0.2109)\end{array}$ & $\begin{array}{c}3.3361 \text { *** } \\
(0.0309)\end{array}$ & $\begin{array}{c}3.2021^{* * *} \\
(0.0495)\end{array}$ & $\begin{array}{c}2.1930 * * * \\
(0.2111)\end{array}$ \\
\hline City Dummies & Yes & Yes & Yes & Yes & Yes & Yes \\
\hline Property Type Dummies & Yes & Yes & Yes & Yes & Yes & Yes \\
\hline Adjusted $\mathrm{R}^{2}$ & 0.9342 & 0.9345 & 0.9349 & 0.9341 & 0.9345 & 0.9349 \\
\hline Observations & 3990 & 3990 & 3990 & 3990 & 3990 & 3990 \\
\hline
\end{tabular}


Next, though fiscal stimuli packages may have been announced in the first quarter of 2020, most of these stimuli packages were being implemented only by the second quarter of 2020 (United Nations 2020). We therefore augment model specification (2) by the interaction term of COVID_Q2 and FISCAL to highlight the real imposition effect of the fiscal stimuli. ${ }^{9}$ We report the results in columns IV to VI in Table 7. In columns IV and $\mathrm{V}$, we continue to find positive and significant coefficients for the interaction variable (albeit marginally significant at the 10\% level). However, we no longer observe significance for the interaction variable in column VI once we include LOG (GDP) as an additional macroeconomic control. Hence, the findings seem to indicate that it is the grand scheme of the fiscal stimuli announcements, instead of merely the implementation of the stimuli packages, that moderates the decline in commercial market rent. Nonetheless, the findings in Table 7 show, to a certain extent, that government fiscal policy responses are deemed to be effective in mitigating the negative impact of the COVID-19 pandemic by restoring confidence in the commercial property market.

\subsection{Robustness Analysis}

We conduct and report various robustness analyses in this section to corroborate our main findings. First, one concern of our findings is that the results are driven by the choice of the sample period. In our sample design, we start our period from 2010, which should alleviate the concern of the contaminating effect of the previous financial crisis back in 2007-2008. Nonetheless, we want to ensure our variable COVID is in fact capturing the impact brought on by the pandemic, and not merely a long-run trend of falling market rent in the Asia-Pacific region that extends from before the pandemic. For that reason, we re-run our empirical analysis of specification (1), but with a more recent subsample period. In the first two columns of Table 8 (I and II), we report the findings when we include only the year of 2019 with the first two quarters of 2020 (COVID), for a total of six quarters, as our subsample period. In columns III and IV, we restrict our sample period to the recent 3 year period to the onset of the pandemic, for a total of 14 quarters. In both subsample tests, we continue to observe negative and significant coefficients for COVID, indicating that the negative impact we observe pertains distinctively to the recent pandemic.

Table 8. Robustness Analysis on Alternative Sample Periods. This table presents the OLS regression estimation results of testing the impact of the COVID-19 pandemic on commercial real estate rent. The dependent variable is LOG (RENT), the natural logarithm of rent for the specific city and property type. The independent variables of interest is COVID. In the first two columns, we restrict our sample to the year of 2019 before the COVID-19 pandemic to the second quarter of 2020. In the last two columns, we restrict our sample to the period of 2017 to the second quarter of 2020. All variables are described in Appendix A. The standard errors are reported in parentheses. ${ }^{* * *}, * *$, and ${ }^{*}$ denote significance of the $\mathrm{t}$-statistics at the $<1 \%$, $5 \%$ and $10 \%$ levels, respectively.

\begin{tabular}{|c|c|c|c|c|}
\hline Variables & I & II & III & IV \\
\hline COVID & $\begin{array}{c}-0.0398 * \\
(0.0207)\end{array}$ & $\begin{array}{c}-0.0447^{*} \\
(0.0275)\end{array}$ & $\begin{array}{c}-0.0477 * * \\
(0.0187)\end{array}$ & $\begin{array}{c}-0.0512 * * \\
(0.0245)\end{array}$ \\
\hline $\operatorname{LOG}(G D P)$ & & $\begin{array}{c}-0.1328 \\
(0.1747)\end{array}$ & & $\begin{array}{c}-0.0675 \\
(0.0916)\end{array}$ \\
\hline POPULATION_CHG & & $\begin{array}{c}0.1132 \\
(0.4236)\end{array}$ & & $\begin{array}{c}0.1315 \\
(0.1343)\end{array}$ \\
\hline UNEMPLOYMENT_CHG & & $\begin{array}{l}-0.0001 \\
(0.0003)\end{array}$ & & $\begin{array}{c}0.0000 \\
(0.0002)\end{array}$ \\
\hline INTEREST_CHG & & $\begin{array}{l}-0.0002 \\
(0.0009)\end{array}$ & & $\begin{array}{l}-0.0000 \\
(0.0007)\end{array}$ \\
\hline POPULATION_DEN & & $\begin{array}{l}-0.0005 \\
(0.0010)\end{array}$ & & $\begin{array}{c}0.0001 \\
(0.0003)\end{array}$ \\
\hline Constant & $\begin{array}{c}3.3012 * * * \\
(0.0731)\end{array}$ & $\begin{array}{c}4.4741^{* * *} \\
(1.4349)\end{array}$ & $\begin{array}{c}3.3020 * * * \\
(0.0488)\end{array}$ & $\begin{array}{c}3.7456 \text { *** } \\
(0.7027)\end{array}$ \\
\hline City Dummies & Yes & Yes & Yes & Yes \\
\hline Property Type Dummies & Yes & Yes & Yes & Yes \\
\hline Adjusted $\mathrm{R}^{2}$ & 0.9451 & 0.9447 & 0.9432 & 0.9430 \\
\hline Observations & 570 & 570 & 1330 & 1330 \\
\hline
\end{tabular}


In our sample, 15 cities are from mainland China, which represents the largest sample country. Moreover, the Chinese real estate market may behave differently given that it was the first country to have discovered the virus. To ensure our results are not predominantly driven by the Chinese cities, we conduct a robustness check for specifications (1) and (2) including only countries and jurisdictions outside of mainland China. Our results reported in Table 9 show that our findings remain robust, as we show that the impact of the COVID-19 crisis remains negative and significant for the coefficients of COVID, COVID_Q1 and COVID_Q2.

Table 9. Robustness Analysis on Subsample Excluding Mainland China. This table presents the OLS regression estimation results of testing the impact of the COVID-19 pandemic on commercial real estate rent on a subsample excluding Mainland Chinese cities. The dependent variable is $L O G$ (RENT), the natural logarithm of rent for the specific city and property type. The independent variables of interest are COVID, COVID_Q1 and COVID_Q2. All variables are described in Appendix A. The standard errors are reported in parentheses. ${ }^{* * *}, * *$, and ${ }^{*}$ denote significance of the $\mathrm{t}$-statistics at the $<1 \%, 5 \%$ and $10 \%$ levels, respectively.

\begin{tabular}{|c|c|c|c|c|}
\hline Variables & I & II & III & IV \\
\hline COVID & $\begin{array}{c}-0.1020 * * * \\
(0.0262)\end{array}$ & $\begin{array}{c}-0.0852^{* * *} \\
(0.0322)\end{array}$ & & \\
\hline COVID_Q1 & & & $\begin{array}{c}-0.1139 * * * \\
(0.0366)\end{array}$ & $\begin{array}{c}-0.0699 * \\
(0.0371)\end{array}$ \\
\hline COVID_Q2 & & & $\begin{array}{c}-0.0900 * * \\
(0.0366)\end{array}$ & $\begin{array}{c}-0.1227^{* *} \\
(0.0559)\end{array}$ \\
\hline$L O G(G D P)$ & & $\begin{array}{c}-0.2443^{* * *} \\
(0.0564)\end{array}$ & & $\begin{array}{c}-0.2509^{* * *} \\
(0.0569)\end{array}$ \\
\hline POPULATION_CHG & & $\begin{array}{c}0.3738^{* * *} \\
(0.0891)\end{array}$ & & $\begin{array}{c}0.3702^{* * * *} \\
(0.0892)\end{array}$ \\
\hline UNEMPLOYMENT_CHG & & $\begin{array}{l}0.0008^{*} \\
(0.0004)\end{array}$ & & $\begin{array}{l}0.0010^{*} \\
(0.0005)\end{array}$ \\
\hline INTEREST_CHG & & $\begin{array}{l}0.0008^{*} \\
(0.0004)\end{array}$ & & $\begin{array}{l}0.0007^{*} \\
(0.0004)\end{array}$ \\
\hline POPULATION_DEN & & $\begin{array}{c}0.0000 \\
(0.0000)\end{array}$ & & $\begin{array}{c}0.0000 \\
(0.0000)\end{array}$ \\
\hline Constant & $\begin{array}{c}3.4469 * * * \\
(0.0350)\end{array}$ & $\begin{array}{c}5.0909 * * * \\
(0.4166)\end{array}$ & $\begin{array}{c}3.4469 * * * \\
(0.0350)\end{array}$ & $\begin{array}{c}5.1389^{* * * *} \\
(0.4207)\end{array}$ \\
\hline City Dummies & Yes & Yes & Yes & Yes \\
\hline Property Type Dummies & Yes & Yes & Yes & Yes \\
\hline Adjusted $\mathrm{R}^{2}$ & 0.9119 & 0.9138 & 0.9119 & 0.9138 \\
\hline Observations & 2394 & 2394 & 2394 & 2394 \\
\hline
\end{tabular}

In our main test, the measures of the severity of the COVID-19 pandemic are on the total confirmed cases and deaths, COVID_CASE and COVID_DEATH. However, in some regions such as South Korea, the spread of COVID-19 has successfully been contained and the growth of COVID-19 cases has substantially declined by the second quarter of 2020. On the other hand, some regions, such as India, reported low numbers of cases at the beginning and then the pandemic simply exploded in these regions. We thus provide alternative measures with NEW_CASE and NEW_DEATH, which, respectively, measurethe number of new confirmed cases and deaths in the specific COVID-19 quarter. We replace these variables in specifications (3) and (4), and the findings reported in Table 10 continue to show that the severity of the COVID-19 pandemic in different regions exerts a differential impact on the regional commercial property market. 
Table 10. Robustness Analysis on New Cases and Deaths. This table presents the OLS regression estimation results of testing the impact of the COVID-19 pandemic on commercial real estate rent. The dependent variable is LOG (RENT), the natural logarithm of rent for the specific city and property type. The independent variables of interest are NEW_CASE, and NEW_DEATH, which represent the new COVID-19 confirmed cases and deaths of each quarter by country/jurisdiction, respectively. All variables are described in Appendix A. The standard errors are reported in parentheses. ${ }^{* * *},{ }^{* *}$, and * denote significance of the $\mathrm{t}$-statistics at the $<1 \%, 5 \%$ and $10 \%$ levels, respectively.

\begin{tabular}{|c|c|c|c|c|}
\hline Variables & $\mathbf{I}$ & II & III & IV \\
\hline NEW_CASE & $\begin{array}{c}-0.0282 \text { ** } \\
(0.0122)\end{array}$ & $\begin{array}{c}-0.0270 \text { ** } \\
(0.0136)\end{array}$ & & \\
\hline NEW_DEATH & & & $\begin{array}{c}-0.9117 * * \\
(0.3960)\end{array}$ & $\begin{array}{c}-0.9269 \text { ** } \\
(0.4503)\end{array}$ \\
\hline LOG (GDP) & & $\begin{array}{c}0.1315^{* * *} \\
(0.0274)\end{array}$ & & $\begin{array}{c}0.1331^{* * *} \\
(0.0274)\end{array}$ \\
\hline POPULATION_CHG & & $\begin{array}{c}0.5255^{* * *} \\
(0.0843)\end{array}$ & & $\begin{array}{c}0.5242^{* * *} \\
(0.0843)\end{array}$ \\
\hline UNEMPLOYMENT_CHG & & $\begin{array}{c}0.0001 \\
(0.0002)\end{array}$ & & $\begin{array}{c}0.0002 \\
(0.0002)\end{array}$ \\
\hline INTEREST_CHG & & $\begin{array}{l}0.0007^{*} \\
(0.0004)\end{array}$ & & $\begin{array}{l}0.0007^{*} \\
(0.0004)\end{array}$ \\
\hline POPULATION_DEN & & $\begin{array}{l}-0.0000 \\
(0.0001)\end{array}$ & & $\begin{array}{l}-0.0000 \\
(0.0001)\end{array}$ \\
\hline Constant & $\begin{array}{c}3.3360 * * * \\
(0.0309)\end{array}$ & $\begin{array}{c}2.2271^{* * *} \\
(0.2098)\end{array}$ & $\begin{array}{c}3.3359 * * * \\
(0.0309)\end{array}$ & $\begin{array}{c}2.2167^{* * * *} \\
(0.2100)\end{array}$ \\
\hline City Dummies & Yes & Yes & Yes & Yes \\
\hline Property Type Dummies & Yes & Yes & Yes & Yes \\
\hline Adjusted $R^{2}$ & 0.9339 & 0.9348 & 0.9339 & 0.9348 \\
\hline Observations & 3990 & 3990 & 3990 & 3990 \\
\hline
\end{tabular}

\section{Concluding Remarks}

In this paper, we provide novel evidence of the impact of the COVID-19 pandemic on the commercial property markets in the Asia-Pacific region. We focus on the private commercial property markets, utilizing timely proprietary market data instead of tracking investor responses from the real estate equity market. Our findings indicate that the COVID19 pandemic has exerted a huge negative impact on market rent. On average, we obtain an estimate that market rent in the Asia-Pacific region has declined by approximately $15 \%$ in the first two quarters of 2020. Moreover, the impact of the pandemic varies across the region according to the severity of the impact of the COVID-19 pandemic. We also show that the retail property sector suffers the most, with average market rent declining over $30 \%$ in the first six months of 2020. Interestingly, when we examine capital values, we find that while capital targeting the retail property sector has been muted, there is some evidence of capital flows into the residential and industrial sectors. We also find government policy interventions serve as effective mechanisms in mitigating the adverse impact of the pandemic. In robustness analysis, we find our results remain intact with different sample subperiods, with a different subsample excluding mainland China that constitutes a substantial proportion of our sample cities, and with alternative measures of the severity of the COVID-19 pandemic. Overall, our study shows that while the effect of the COVID-19 public health crisis is detrimental to commercial real estate, its impact varies significantly across different regions and property sectors.

Our findings quantify and document the impact of the COVID-19 pandemic, an unprecedented public health crisis, on the commercial property market. Though our test period is short, we show some novel evidence that market rent responds immediately to the public health crisis. Moreover, our additional analysis on capital values provides interesting complementary evidence that market participants might have concerns on the eventual recovery of the retail property market, and consequently they have diverted their capital to the other property sectors. We further show that government fiscal stimuli exert 
some impact on restoring confidence in the commercial property market. In so doing, our study highlights that opportunities exist given the interesting dynamics of the commercial property market amid the COVID-19 crisis.

A notable limitation of our study is that our sample period ends in the second quarter of 2020, and we urge future research to continue to examine the recovery period from the COVID-19 crisis. It might also be interesting to examine the recent relapse in the commercial property market due to the finding of variants of the COVID-19 virus. While it might be too early to foresee the complete story of the resilience of the overall commercial property market from our data, we offer some important first evidence on the impact of the COVID-19 pandemic on the commercial real estate market. Given that our proprietary data cover the Asia-Pacific region, which represents a substantial proportion of the global market, our findings bear important implications on how the pandemic has impacted the global commercial property landscape. Lastly, we show how governments could aid in market recovery by limiting the spread of the virus as well as imposing fiscal interventions to stimulate the economy.

Author Contributions: All authors contributed equally to this article. All authors have read and agreed to the published version of the manuscript.

Funding: The authors would like to thank the JLL for funding the data.

Institutional Review Board Statement: Not applicable.

Informed Consent Statement: Not applicable.

Data Availability Statement: This study uses proprietary REIS data from JLL as well as publicly available economic data.

Acknowledgments: The authors acknowledge Jones Lang LaSalle (JLL) for providing the data. The opinions expressed in this paper do not necessarily reflect those of JLL. The authors would like to thank the editor and reviewers of the Journal, participants at the PRRES Conference 2021, and Chongyu Wang for their helpful comments. All errors are our own.

Conflicts of Interest: The authors declare no conflict of interest.

Appendix A

Table A1. Variables Definition. This table presents definition of the variables used in the empirical tests.

\begin{tabular}{ll}
\hline \multicolumn{1}{c}{ Variables } & \multicolumn{1}{c}{ Definition } \\
\hline RENT & $\begin{array}{l}\text { Average net effective rent or net rent, summed and averaged across the submarkets for each market } \\
\text { and sector, in USD per square meter per year. }\end{array}$ \\
\hline COVID & Equals to 1 if it is during the COVID-19 pandemic period (2020Q1 and 2020Q2); zero otherwise. \\
\hline COVID_Q1 & Equals to 1 if it is in 2020Q1, zero otherwise. \\
\hline COVID_Q2 & Equals to 1 if it is in 2020Q2, zero otherwise. \\
\hline GDP & $\begin{array}{l}\text { Quarterly Gross Domestic Product (GDP) per-capita in million and in USD (country/jurisdiction } \\
\text { level). }\end{array}$ \\
\hline POPULATION_CHG & Quarter-to-quarter percentage change in total population (country/jurisdiction level). \\
\hline UNEMPLOYMENT_CHG & Quarter-to-quarter percentage change in unemployment rate (country/jurisdiction level). \\
\hline INTEREST_CHG & $\begin{array}{l}\text { Quarter-to-quarter percentage change in interest rate, obtained from Central Bank Policy } \\
\text { (country/jurisdiction level). }\end{array}$ \\
\hline POPULATION_DEN & $\begin{array}{l}\text { Population density, measured as total population divided by land area in square kilometer } \\
\text { (country/jurisdiction level). }\end{array}$ \\
\hline COVID_CASE & $\begin{array}{l}\text { Total number of COVID-19 confirmed cases as of 30 June 2020 (country/jurisdiction level). The data } \\
\text { are divided by 100,000. }\end{array}$ \\
\hline
\end{tabular}


Table A1. Cont.

\begin{tabular}{ll}
\hline \multicolumn{1}{c}{ Variables } & \multicolumn{1}{c}{ Definition } \\
\hline COVID_DEATH & Total number of COVID-19 deaths (country/jurisdiction level). The data are divided by 100,000. \\
\hline OFFICE & Equals to 1 if it is office property, zero otherwise. \\
\hline RETAIL & Equals to 1 if it is retail property, zero otherwise. \\
\hline INDUSTENTIAL & Equals to 1 if it is residential property, zero otherwise. \\
\hline CAPITAL_VALUE & Equals to 1 if it is industrial property, zero otherwise. \\
\hline FISCAL & $\begin{array}{l}\text { Average capital value, summed and averaged across all submarkets for each market and sector, in } \\
\text { USD per square meter. Capital value is the implicit base price payable per square meter of area, } \\
\text { estimated as the current market rent divided by the market yield at the same point in time. }\end{array}$ \\
\hline NEW_CASE & Fiscal support package, in millions and in USD (country/jurisdiction level). \\
\hline NEW_DEATH & $\begin{array}{l}\text { Number of new COVID-19 confirmed cases in each quarter (country/jurisdiction level). The data are } \\
\text { divided by 100,000. }\end{array}$ \\
\hline
\end{tabular}

\section{Notes}

1 For instance, a restaurant survey shows that $53 \%$ of respondents had to shut down their operations entirely at the end of March 2020 (American Express 2020).

2 Unfortunately, JLL does not collect in-house data for the hotel sector, which is also deeply impacted by the COVID-19 pandemic.

3 The numbers of average total confirmed cases and deaths, and average new cases and deaths, seem low because they are calculated over the whole sample period. The average numbers of cases and deaths per region amount to 69,953 and 2264 over the COVID-19 period. Similarly, the average new cases and new deaths amount to 62,562 and 2267, respectively, for the first two quarters of 2020 .

4 The average fiscal stimulus amounts to $\$ 384,162$ million USD if we focus solely on the first two quarters of 2020.

5 In un-tabulated results, we also obtain similar findings when we examine the severity of the COVID-19 pandemic with confirmed cases and deaths as in specifications (3) and (4).

6 For countries or jurisdictions with missing information from ESCAP, we further search local news sources for the respective country or jurisdiction.

7 The numbers are further divided by 100,000 in order to show the values of coefficients in the empirical analysis.

8 Since fiscal stimuli have a direct effect on GDP, it is expected the variable FISCAL would be highly correlated with contemporaneous GDP. Hence, we present regression results with and without the inclusion of $L O G(G D P)$ as a control variable in columns II and III, respectively.

9 Unfortunately, since countries and jurisdictions may not disclose the exact dates and the sub-amounts on the implementation of some of their fiscal policies, it is impossible for us to further disentangle the fiscal stimuli amounts into the quarters.

\section{References}

Acharya, Viral, and Sascha Steffen. 2020. The risk of being a fallen angel and the corporate dash for cash in the midst of COVID. CEPR COVID Economics 10: 44-61.

Adams, Zeno, and Roland Füss. 2010. Macroeconomic determinants of international housing markets. Journal of Housing Economics 19: 38-50. [CrossRef]

Agnello, Luca, Vitor Castro, and Ricardo M. Sousa. 2017. Systematic financial crises and the housing market cycle. Applied Economics Letters 25: 724-29. [CrossRef]

Akinsomi, Omokolade. 2020. How resilient are REITs to a pandemic? The COVID-19 effect. Journal of Property Investment E Finance 39: 19-24. [CrossRef]

Albuquerque, Rui, Yrjo Koskinen, Shuai Yang, and Chendi Zhang. 2020. Resiliency of environmental and social stocks: An analysis of the exogenous COVID-19 market crash. The Review of Corporate Finance Studies 9: 593-621. [CrossRef]

Alfaro, Laura, Anusha Chari, Andrew N. Greenland, and Peter K. Schott. 2020. Aggregate and Firm-Level Stock Returns during Pandemics, in Real Time. NBER Working Paper Series No. 26950. Available online: http://www.nber.org/papers/w26095 (accessed on 11 September 2020).

Ambrus, Attila, Erica Field, and Robert Gonzalez. 2020. Loss in the time of Cholera: Long-run impact of a disease epidemic on the urban landscape. American Economic Review 110: 475-525. [CrossRef] 
American Express. 2020. COVID-19: Future Trends in Food and Beverage Industry. Available online: https://www.americanexpress. com/en-ca/business/trends-and-insights/articles/covid-19--future-trends-in-food-and-beverage-industry/ (accessed on 28 July 2021).

An, Xudong, Yongheng Deng, Jeffrey D. Fisher, and Maggie Rong Hu. 2016. Commercial real estate rental index: A dynamic panel data model estimation. Real Estate Economics 44: 378-410. [CrossRef]

Archer, Wayne R., and David C. Ling. 2012. Real Estate Principles: A Value Approach, 4th ed. New York: McGraw-Hill/Irwin.

Baffoe-Bonnie, John. 1998. The dynamic impact of macroeconomic aggregates on housing prices and stock of houses: A national and regional analysis. Journal of Real Estate Finance and Economics 17: 179-97. [CrossRef]

Baker, Scott R., Nicholas Bloom, Steven J. Davis, Kyle Kost, Marco Sammon, and Tasaneeya Viratyosin. 2020. The unprecedented stock market reaction to COVID-19. The Review of Asset Pricing Studies 10: 742-58. [CrossRef]

Barro, Robert, José Ursúa, and Joanna Weng. 2020. The Coronavirus and the Great Influenza Pandemic: Lessons from the "Spanish Flu" for the Coronavirus' Potential Effects on Mortality and Economic Activity. NBER Working Paper Series No. 26866. Available online: http:/ / www.nber.org/papers/w26866 (accessed on 15 September 2020).

Blank, David M., and Louis Winnick. 1953. The structure of the housing market. The Quarterly Journal of Economics 67: 181-208. [CrossRef]

Bleakley, Hoyt. 2007. Disease and development: Evidence from hookworm eradication in the American South. The Quarterly Journal of Economics 122: 73-117. [CrossRef] [PubMed]

Brounen, Dirk, and Maarten Jennen. 2009. Local office rent dynamics. Journal of Real Estate Finance and Economics 39: 385-402. [CrossRef]

Campbell, Sean D., Morris A. Davis, Joshua Gallin, and Robert F. Martin. 2009. What moves housing markets: A variance decomposition of the rent-price ratio. Journal of Urban Economics 66: 90-102. [CrossRef]

Chau, Kwong Wing, and Siu Kei Wong. 2016. Information asymmetry and the rent and vacancy rate dynamics in the office market. Journal of Real Estate Finance and Economics 53: 162-83. [CrossRef]

Chen, Chen, Sudipto Dasgupta, Thanh Huynh, and Ying Xia. 2020. Were Stay-at-Home Orders during the COVID-19 Harmful for Business?-The Market's View. Working Paper. Hong Kong: Monash University, and Chinese University of Hong Kong.

Chiang, Ming-Chu, I-Chun Tsai, and Tien-Foo Sing. 2013. Are REITs a good shelter from financial crises? Evidence from Asian markets. Journal of Property Investment \& Finance 31: 237-53.

Chou, Ji, Nai-Fong Kuo, and Su-Ling Peng. 2004. Potential impacts of the SARS outbreak on Taiwan's economy. Asian Economic Papers 3: 84-99. [CrossRef]

Correia, Sergio, Stephan Luck, and Emil Verner. 2020. Pandemics Depress the Economy, Public Health Interventions Do Not: Evidence from the 1918 Flu. Working Paper. New York: Federal Reserve Board, Federal Reserve Bank of New York, and MIT. [CrossRef]

D'Arcy, Eamonn, Tony McGough, and Sotiris Tsolacos. 1999. An econometric analysis and forecasts of the office rental cycle in the Dublin area. Journal of Property Research 16: 309-21. [CrossRef]

D'Lima, Walter, Luis A. Lopez, and Archana Pradhan. 2020. COVID-19 and Housing Market Effects: Evidence from U.S. Shutdown Orders. Working Paper. Norfolk: Old Dominion University.

De Francesco, Anthony J. 2008. Time-series characteristics and long-run equilibrium for major Australian office markets. Real Estate Economics 36: 371-402. [CrossRef]

De Vito, Antonio, and Juan-Pedro Gomez. 2020. Estimating the COVID-19 cash crunch: Global evidence and policy. Journal of Accounting and Public Policy 39: 1-14. [CrossRef]

Devos, Erik, Seow-Eng Ong, Andrew C. Spieler, and Desmond Tsang. 2013. REIT institutional ownership dynamics and the financial crisis. Journal of Real Estate Finance and Economics 47: 266-88. [CrossRef]

Ding, Haoyuan, Haichao Fan, and Shu Lin. 2020a. COVID-19, Firm Exposure, and Firm Value: A Tale of Two Lockdowns. Working Paper. SSRN: 3574401. Shanghai: Shanghai University of Finance and Economics, Shanghai: Fudan University and Shanghai Institute of International Finance and Economics, Hong Kong: Chinese University of Hong Kong.

Ding, Wenzhi, Ross Levine, Chen Lin, and Wensi Xie. 2020b. Corporate Immunity to the COVID-19 Pandemic. NBER Working Paper Series No. 27055. Available online: http:/ / www.nber.org/papers/w27055 (accessed on 10 September 2020).

Edelstein, Robert H., and Desmond Tsang. 2007. Dynamic residential housing cycles analysis. Journal of Real Estate Finance and Economics 35: 295-313. [CrossRef]

Eichholtz, Piet, Ronald Huisman, Kees Koedijk, and Lisa Schuin. 1998. Continental factors in international real estate returns. Real Estate Economics 26: 493-509. [CrossRef]

Fahlenbrach, Rüdiger, Kevin Rageth, and René M. Stulz. 2020. How Valuable if Financial Flexibility when Revenue Stops? Evidence from the COVID-19 Crisis? NBER Working Paper Series No. 27106. Available online: http://www.nber.org/papers/w27106 (accessed on 13 September 2020).

Francke, Marc, and Matthijs Korevaar. 2021. Housing Markets in a Pandemic: Evidence from Historical Outbreaks. Journal of Urban Economics 123: 103333. [CrossRef]

Gallin, Joshua. 2008. The long-run relationship between house prices and rents. Real Estate Economics 36: 635-58. [CrossRef]

Gerding, Felix, Thorsten Martin, and Florian Nagler. 2020. Sovereign Debt and Equity Returns in the Face of Disaster. Working Paper. Milan: Bocconi University. [CrossRef] 
Gilchrist, Kate. 2020. Real Estate Is Still a Popular Investment Pick. Here's What You Need to Know about Buying in a Downturn. CNBC, May 11. Available online: https://www.cnbc.com/2020/05/12/investing-advice-real-estate-investment-buying-a-homein-a-downturn.html(accessed on 30 September 2020).

Goodhart, Charles, and Boris Hofmann. 2008. House price, money, credit, and the macroeconomy. Oxford Review of Economic Policy 24: 180-205. [CrossRef]

Griffiths, James. 2020. As Coronavirus Spread through Asia, the West Had a Head Start to Prepare. Why Wasn't It Used? CNN, April 17. Available online: https://www.cnn.com/2020/04/16/asia/asia-europe-us-coronavirus-delay-intl-hnk/index.html(accessed on 29 September 2020).

Hassan, Tarek Alexander, Stephan Hollander, Laurence Van Lent, Markus Schwedeler, and Ahmed Tahoun. 2020. Firm-Level Exposure to Epidemic Diseases: COVID-19, SARS, and H1N1. NBER Working Paper Series No. 26971. Available online: http:/ / www.nber.org/papers/w26971 (accessed on 12 September 2020).

Hendershott, Patric H., Bryan D. MacGregor, and Raymond Y. C. Tse. 2002a. Estimation of the rental adjustment process. Real Estate Economics 30: 165-83. [CrossRef]

Hendershott, Patric H., Bryan MacGregor, and Michael White. 2002b. Explaining real commercial rents using an error correction model with panel data. Journal of Real Estate Finance and Economics 24: 59-87. [CrossRef]

Hendershott, Patric H., Colin M. Lizieri, and Bryan D. MacGregor. 2010. Asymmetric adjustment in the city of London office market. Journal of Real Estate Finance and Economics 41: 80-101. [CrossRef]

Ibanez, Maria R., and Anthony Pennington-Cross. 2013. Commercial property rent dynamics in U.S. metropolitan areas: An examination of office, industrial, flex and retail space. Journal of Real Estate Finance and Economics 46: 232-59. [CrossRef]

Invesco. 2020. The impact of novel coronavirus (COVID-19) on Asia Pacific real estate. Invesco Real Estate Insight, February 19.

JLL. 2020a. Global commercial real estate markets feel impact of COVID-19. JLL, August 11.

JLL. 2020b. What does coronavirus mean for Asia Pacific real estate? JLL, February 12.

Keogh-Brown, Marcus R., Simon Wren-Lewis, W. John Edmunds, Philippe Beutels, and Richard D. Smith. 2010. The possible macroeconomic impact on the UK of an influenza pandemic. Health Economics 19: 1345-60. [CrossRef]

Lagoarde-Segot, Thomas, and Patrick L. Leoni. 2013. Pandemics of the poor and banking stability. Journal of Banking E Finance 37: 4574-83.

Li, Kai, Xing Liu, Feng Mai, and Tengfei Zhang. 2021. The Role of Corporate Culture in Bad Times: Evidence from the COVID-19 Pandemic. Journal of Financial and Quantitative Analysis, 1-68. [CrossRef]

Lilley, Andrew, Matthew Lilley, and Gianluca Rinaldi. 2020. Public Health Interventions and Economic Growth: Revisiting the 1918 Flu Evidence. Working Paper. Cambridge: Harvard University.

Ling, David C., Chongyu Wang, and Tingyu Zhou. 2020. A first look at the impact of COVID-19 on commercial real estate prices: Asset level evidence. The Review of Asset Pricing Studies 10: 669-704. [CrossRef]

Mikhed, Vyacheslav, and Petr Zemčík. 2009. Do house prices reflect fundamentals? Aggregate and panel data evidence. Journal of Housing Economics 18: 140-49. [CrossRef]

Milcheva, Stanimira. 2020. Volatility and the Cross-Section of Real Estate Equity Returns during COVID-19. Working Paper. London: University College London.

OECD. 2020a. COVID-19 and the retail sector: Impact and policy responses. OECD Policy Responses to Coronavirus (COVID-19), June 16.

OECD. 2020b. OECD Economic Outlook. Paris: Organization for Economic Corporation and Development (OECD).

Ozili, Peterson K., and Thankom Arun. 2020. Spillover of COVID-19: Impact on the Global Economy. Working Paper. Rochester: SSRN. [CrossRef]

Pagano, Marco, Christian Wagner, and Josef Zechner. 2020. Disaster Resilience and Asset Prices. Working Paper. Naples: University of Naples Federico II.

Papanikolaou, Dimitris, and Lawrence D. W. Schmidt. 2020. Working Remotely and the Supply-Side Impact of COVID-19. NBER Working Paper Series No. 27330. Available online: http:/ / www.nber.org/papers/w27330 (accessed on 10 September 2020).

Pettersson, Henrik, Byron Manley, and Sergio Hernandez. 2020. Tracking Coronavirus' Global Spread. CNN, September 29. Available online: https: / / www.cnn.com/interactive/2020/health/coronavirus-maps-and-cases/(accessed on 29 September 2020).

Quigley, John M. 2001. Real estate and the Asian crisis. Journal of Housing Economics 10: 129-61. [CrossRef]

Ramelli, Stefano, and Alexander F. Wagner. 2020. Feverish Stock Price Reactions to COVID-19. Swiss Finance Institute Research Paper No. 20-12. Zürich: Swiss Finance Institute.

Rogers, Tom. 2020. The Economic Impact of COVID-19 on Asian-Pacific. Oxford: Oxford Economics.

Rosen, Kenneth T., and Lawrence B. Smith. 1983. The price-adjustment process for rental housing and the natural vacancy rate. American Economic Review 73: 779-86.

Schoenfeld, Jordan. 2020. The Invisible Risk: Pandemics and the Financial Markets. Working Paper. Hanover: Dartmouth College.

Shan, Chenyu, and Dragon Yongjun Tang. 2020. The Value of Employee Satisfaction in Disastrous Times: Evidence from COVID-19. Working Paper. Shanghai: Shanghai University of Finance and Economics.

Shilling, James D., C. F. Sirmans, and John B. Corgel. 1987. Price adjustment process for rental office space. Journal of Urban Economics 22: 90-100. [CrossRef]

Slade, Barrett. 2000. Office rent determinants during market decline and recovery. Journal of Real Estate Research 20: 357-80. [CrossRef] Tay, Shirley. 2019. China is driving Growth in Asia's Real Estate Market Despite Trade WAR headwinds, Report Finds. CNBC, May 24. 
United Nations. 2020. Policy Responses to COVID-19 in Asia and the Pacific. Bangkok: United Nations Economic and Social Commission for Asia and the Pacific. Available online: https://www.unescap.org/covid19/policy-responses (accessed on 19 October 2020).

UNWTO. 2020. Impact Assessment of the COVID-19 Outbreak on International Tourism. Available online: https://www.unwto.org/ impact-assessment-of-the-covid-19-outbreak-on-international-tourism (accessed on 28 July 2021).

Van Dijk, Dorinth, Anne Kinsella Thompson, and David Geltner. 2020. COVID-19 Special Report: Recent Drops in Market Liquidity May Foreshadow Major Price Drops in U.S. Commercial Real Estate Markets. Cambridge: MIT Center for Real Estate.

Wachter, Jessica A. 2013. Can time-varying risk of rare disasters explain aggregate stock market volatility? Journal of Finance 68: 987-1035. [CrossRef]

Wheaton, William C., and Raymond G. Torto. 1988. Vacancy rates and the future of office rents. Journal of the American Real Estate and Urban Economics Association 16: 430-36. [CrossRef]

Wheaton, William C., Raymond G. Torto, and Peter Evans. 1997a. The cyclic behavior of the greater London office market. Journal of Real Estate Finance and Economics 15: 77-92. [CrossRef]

Wheaton, William, Raymond Torto, and Jon Southard. 1997b. The CB commercial/Torto Wheaton Database. Journal of Real Estate Literature 5: 59-66. [CrossRef]

Wong, Grace. 2008. Has SARS infected the property market? Evidence from Hong Kong. Journal of Urban Economics 63: 74-95. [CrossRef] [PubMed]

Xie, Lingshan, and Stanimira Milcheva. 2020. Proximity to COVID-19 Cases and Real Estate Equity Returns. Working Paper. London: University College London.

Zhang, Xiaoqi, Zheng Ji, Yanqiao Zheng, Xinyue Ye, and Dong Li. 2020. Evaluating the effect of city lock-down on controlling COVID-19 propagation through deep learning and network science models. Cities 107: 102869. [CrossRef]

Zhao, Yunhui. 2020. U.S. Housing Market during COVID-19: Aggregate and Distributional Evidence. Working Paper. Washington, DC: IMF. 